Georgia State University

ScholarWorks @ Georgia State University

\title{
The Psychological Costs of War: Military Combat and Mental Health
}

Resul Cesur

Georgia State University, cesur@gsu.edu

Joseph J. Sabia

San Diego State University, Joe_Sabia@yahoo.com

Erdal Tekin

Georgia State University, tekin@gsu.edu

Follow this and additional works at: https://scholarworks.gsu.edu/uwrg_workingpapers

\section{Recommended Citation}

Cesur, Resul; Sabia, Joseph J.; and Tekin, Erdal, "The Psychological Costs of War: Military Combat and Mental Health" (2011). UWRG Working Papers. 41.

https://scholarworks.gsu.edu/uwrg_workingpapers/41

This Article is brought to you for free and open access by the Usery Workplace Research Group at ScholarWorks @ Georgia State University. It has been accepted for inclusion in UWRG Working Papers by an authorized administrator of ScholarWorks @ Georgia State University. For more information, please contact scholarworks@gsu.edu. 
Andrew Young School of Policy Studies Research Paper Series

Working Paper 11-26

March 2011

Department of Economics

W.J. Usery Workplace Research Group

\title{
The Psychological Costs of War: Military Combat and Mental Health
}

\author{
Resul Cesur \\ Georgia State University
}

Joseph J. Sabia San Diego State University

\section{Erdal Tekin} Georgia State University 
Working Paper 2011-3-1

March 2011

\section{The Psychological Cost of}

War: Military Combat and

Mental Health

\section{Resul Cesur}

Georgia State University

Joseph Sabia

San Diego State University

\section{Erdal Tekin}

Georgia State University 


\title{
The Psychological Costs of War: Military Combat and Mental Health*
}

\author{
Resul Cesur \\ University of Connecticut ${ }^{* *}$ and Georgia State University \\ Department of Economics \\ Andrew Young School of Public Policy \\ Email: cesur@gsu.edu
}

\author{
Joseph J. Sabia \\ United States Military Academy and San Diego State University \\ Office of Economic and Manpower Analysis \\ Department of Economics \\ Email: joe_sabia@yahoo.com \\ Erdal Tekin \\ Georgia State University, IZA and NBER \\ Department of Economics \\ Andrew Young School of Public Policy \\ Email: tekin@gsu.edu
}

\section{April 2011}

\footnotetext{
* The authors thank Daniel Rees, John Z. Smith, David Lyle, and seminar participants at the University of Connecticut, and the 2010 Southern Economic Association Meetings for useful comments and suggestions on an earlier draft of this paper. Thanks also to Whitney Dudley for excellent research assistance. The views expressed herein are those of the authors and do not reflect the position of the United States Military Academy, the Department of the Army, or the Department of Defense. This research uses data from Add Health, a program project designed by J. Richard Udry, Peter S. Bearman, and Kathleen Mullan Harris, and funded by a grant P01-HD31921 from the National Institute of Child Health and Human Development, with cooperative funding from 17 other agencies. Special acknowledgment is due Ronald R. Rindfuss and Barbara Entwisle for assistance in the original design. Persons interested in obtaining data files from Add Health should contact Add Health, Carolina Population Center, 123 W. Franklin Street, Chapel Hill, NC 27516-2524 (http://www.cpc.unc.edu/addhealth/contract.html).

*** At the Department of Finance effective August 2011.
} 


\title{
The Psychological Costs of War: Military Combat and Mental Health
}

\begin{abstract}
While descriptive evidence suggests that deployment in the Global War on Terrorism is associated with adverse mental health, the causal effect of combat is not well established. Using data drawn from the National Longitudinal Study of Adolescent Health, we exploit exogenous variation in deployment assignment and find that soldiers deployed to combat zones where they engage in frequent enemy firefight or witness allied or civilian deaths are at substantially increased risk for suicidal ideation, psychological counseling, and post-traumatic stress disorder (PTSD). Our estimates imply lower-bound health care costs of $\$ 1.5$ to $\$ 2.7$ billion for combat-induced PTSD.
\end{abstract}

Keywords: military service, post-traumatic stress disorder, depression 
"This is the price of war....You can't send young Americans to Iraq and Afghanistan ... and expect them to come home and just fit right in. They bring that trauma with them."

-Max Cleland, Vietnam War Veteran and former U.S. Senator

\section{Introduction}

The mental health impairments experienced by U.S. soldiers deployed in the Global War on Terrorism (GWOT) have received a great deal of attention by both policymakers and the American news media. A recent article in the Time magazine describes the mental health problems of servicemen and women returning from Iraq and Afghanistan as “the U.S. Army's third front" (Thompson, 2010). Military service has been linked to greater take-up of disability benefits among some veterans (Autor et al., 2011; Angrist et al., 2010), as well as higher rates of crime and violence (Rohlfs, 2010). ${ }^{1}$ The Centers for Disease Control and Prevention estimates that veterans comprise nearly 20 percent of the more than 30,000 suicides each year. Public concern about the mental health problems of soldiers has prompted political action, with President Barack Obama announcing a plan to increase the ease with which veterans diagnosed with post-traumatic stress disorder (PTSD) can receive federal health benefits (Obama, 2010).

While a number of recent studies have found that PTSD is a growing problem for U.S. soldiers deployed in Operation Iraqi Freedom and Operation Enduring Freedom (Shen et al., 2009a, b; Hoge et al., 2006, 2004; Erbes et al., 2007; Rosenheck and Fontana, 2007; Seal et al., 2007; Tanielian and Jaycox, 2008), much of this work has been descriptive in nature. Those studies that have used regression strategies (Shen et al., 2009ab, Rona et al., 2007) have been hampered by data limitations that fail to adequately address the endogeneity of military service or to disentangle the effects of deployment length from exposure to violent combat events.

\footnotetext{
${ }^{1}$ Angrist et al. (2010) find greater disability take-up among Vietnam veterans with low earning potential. Autor et al. (2011) also find evidence of a recent increase in disability uptake among Vietnam veterans but are unable to distinguish whether this effect is driven by a long-term adverse health effect of combat or a recent liberalization in benefit rules.
} 
Using data drawn from the National Longitudinal Study of Adolescent Health, we examine the relationship between military combat and young adults' mental health while carefully addressing the role of individual-level unobserved heterogeneity by controlling for mental health prior to deployment as well as exploiting plausibly exogenous variation in deployment assignment and exposure to violent combat events. We rely on evidence that deployment assignments of active-duty units are unrelated to the characteristics of soldiers or their families (Engel et al, 2010; Lyle, 2006) to identify the causal effects of combat.

We find that active-duty U.S. soldiers serving in combat zones are at greater risk of PTSD and are more likely to receive psychological or emotional counseling than their activeduty counterparts serving outside the United States in non-combat zones. Our preferred estimates suggest that combat-induced PTSD in the GWOT imposes two-year costs of $\$ 1.5$ to \$2.7 billion on the U.S. health care system.

We find that the psychological costs of combat are largest for soldiers exposed to violent combat events such as frequent enemy firefight. Soldiers who kill someone (or believe they have killed someone), are injured in combat, or witness the death or wounding of a civilian or coalition member are at substantially increased risk of suicidal ideation, depressive symptomatology, and PTSD. Our findings suggest that military policymakers crafting optimal deployment schedules that account for soldiers' mental health should focus greater attention on soldiers' experiences with frequent enemy firefight as opposed to cumulative deployment length.

\section{Background}

A recent comprehensive review of the literature on military service, mental health, and PTSD concluded that active duty officers, particularly those who have served and are serving in 
combat in Iraq and Afghanistan during the Global War on Terrorism (GWOT), suffer substantial mental health problems (Tanielian and Jaycox, 2008). This review finds that 26 percent of active duty soldiers returning from serving in the GWOT suffer from depression, drug and alcohol dependency, homelessness, or suicide. Estimates of PTSD rates among those who served in Iraq or Afghanistan ranged from 4 to 45 percent (Tanielian and Jaycox, 2008). However, most of the studies on which these conclusions are based are descriptive in nature (see, for example, Hoge et al, 2006, 2004), without a counterfactual control group to estimate the effect of military service on psychological well-being.

Distinguishing the mental health effects of military service from associations due to hardto-measure characteristics of soldiers is a daunting task. This empirical difficulty also presents a significant obstacle to the efforts of policymakers who wish to estimate the health care costs of combat-induced mental health problems. For instance, Tanielian and Jaycox (2008) obtain a two-year cost estimate for PTSD by assuming that the prevalence rate of PTSD for deployed soldiers is equivalent to the effect of combat service. However, the authors do not construct a counterfactual comparison group and therefore assume that in the absence of service, no combat personnel would suffer from adverse mental health.

The most common comparison group constructed by researchers examining the health effects of military service has been civilians (Jordan et al., 1991; Iowa Persian Gulf Study Group, 1997; McFall et al., 1992; Price et al., 2004; Card, 1987; McKiney et al., 1997; Kang and Bullman, 2001). ${ }^{2}$ But, as Dobkin and Shabani (2009) note, the average individual and family background characteristics of active duty servicemen are quite different from those of civilians,

\footnotetext{
${ }^{2}$ A related literature on civilians has examined the mental health consequences of stressful domestic occupations such as police work (Wang et al., 2010; Liberman et al., 2002) and firefighting (Bryant and Guthrie, 2005; 2007; Heinrichs et al., 2005).
} 
and many of these characteristics are also related to psychological well-being. If, for example, socioeconomic status is negatively related to the probability of joining the armed forces (Segal et al., 1998; Bachman et al., 2000; Kleykamp, 2006) and positively related to mental health (Miech et al., 1999), then members of military may be prone to mental health problems even in the absence of military service, leading to overstated estimates of the cost of combat service. On the other hand, because military personnel go through a rigorous health screening prior to induction or commissioning (see, for example, Department of Defense Directives 6130.3 and 6130.4), individuals who serve in the military may not only be in better physical health than their civilian counterparts, but they may also be in better mental health as well. Moreover, young people with higher educational aspirations may both enlist in the military to earn educational benefits for themselves or their families (Kleykamp, 2006) and be better equipped to cope with future mental health problems. ${ }^{3}$ Each of these forms of selection would tend to understate the estimated effects of combat service.

More convincing studies of the health effects of military service have focused on service in the Second World War, the Korean War, and the Vietnam War, and have addressed the endogeneity of military service by using the draft lottery as an instrument (Angrist et al., 2010; Hearst et al., 1986; Bedard and Deschenes, 2004; Dobkin and Shabani, 2009; Edwards and MacLean, 2010). Using this approach, Angrist et al. (2010) and Dobkin and Shabani (2009) find evidence that prior estimates of the health effects of military service were overstated due to individual heterogeneity. However, the results still suggest that military service may adversely affect health. Hearst et al. (1986) find that draft exposure was associated with an increased risk of suicide and automobile accidents and Bedard and Deschenes (2004) find that veterans of

\footnotetext{
${ }^{3}$ Moreover, recent descriptive work by National Priorities Project (2008) suggests that negative selection on socioeconomic status may not be as severe today.
} 
World War II and the Korean War were at substantial increased risk of mortality due to militaryinduced smoking.

The absence of a draft in the post-Vietnam era does not allow such an identification approach to study the effect of randomly drawing a civilian for service in the GWOT. However, researchers in the post-draft era have identified a potentially new source of exogeneous variation in combat experiences among soldiers: the U.S. military's deployment assignment procedures. Two recent studies (Lyle, 2006 and Engel et al., 2010) have persuasively argued that deployment assignment is exogenous to soldiers' preferences, welfare, and family-level characteristics. For example, Engel et al. (2010) note that the U.S. Army almost never deploys individual soldiers, but rather deploys companies. An individual soldier has little control over the company to which he or she is assigned and, as matter of policy, is reassigned every 3 or 4 years by Army Human Resources Command. The timing and location of companies' deployment assignments depend on the circumstances of the military operation and the readiness and availability of the unit (Engel et al., 2010). Thus, deployment assignments of soldiers are not based on individual soldiers' characteristics such as perceived bravery, mental toughness, or family circumstances, but rather based on the operational needs of the Armed Forces:

"The 'needs of the army'...captures the essence of all [military] assignments: world events drive army assignments. [T]he timing of the move and assignment of a soldier to a subordinate army unit are largely independent of a soldier's preferences... [O]nce a soldier is assigned to a division, the division assigns the soldier to one of several brigades, the brigade assigns the soldier to one of several battalions, and the battalion assigns the soldier to one of several companies. The 'needs of the army' also determine the missions that a soldier's company receives.” (Lyle, 2006, p. 323) 
While Lyle (2006) and Engel et al. (2010) use unit deployment assignments to estimate the causal effect of deployment-induced parental absences on children's academic achievement, no study of which we are aware has exploited variation in deployment assignments to identify the mental health effects of combat experiences.

Three recent studies have examined the relationship between length of combat service and mental health during the Global War on Terrorism using military records (Rona et al., 2007; Shen et al., 2009ab). Their findings suggest that longer deployment lengths are associated with a greater risk for a positive PTSD screening. While intriguing, these findings do not make clear whether deployment length itself is the cause of mental health problems or whether it is the effects of exposure to psycho-traumatic combat events that may be correlated with deployment length. Disentangling the effects of deployment length from combat events is important for military policymakers who wish to design deployment schedules that minimize mental health problems of soldiers.

Our study contributes to the literature on the effects of military combat in the GWOT in several important ways. First, our study is the first to use longitudinal data on military service and mental health, which allows us to condition on mental health prior to deployment. ${ }^{4}$ Second, we exploit plausibly exogenous variation in deployment assignment and exposure to violent combat events to better isolate the causal effect of GWOT combat experience on psychological well-being. Finally, our study is the first to explore the mental health effects of specific violent combat events, including engaging the enemy in firefight, killing or wounding someone, and observing the death or wounding of civilians, coalition/allied soldiers, and enemy soldiers.

\footnotetext{
${ }^{4}$ Our models also control for school fixed effects to account for unobserved heterogeneity at the neighborhood level and family fixed effects to control for fixed family-level heterogeneity.
} 


\section{Data and Measures}

The data used in this study come from the National Longitudinal Study of Adolescent Health (Add Health), which was conducted by the Carolina Population Center at the University of North Carolina at Chapel Hill. The Add Health is a nationally representative school-based longitudinal study that began surveying U.S. adolescents in seventh to twelfth grades in the mid1990s. The Wave I in-home baseline survey was administered to 20,745 respondents during the 1994-1995 academic year. Three follow-ups have been conducted since the original Add Health data collection effort. The first follow-up, the Wave II in-home survey, was conducted in 1996, approximately one year after the baseline survey; the second follow-up (Wave III) was administered in 2001, and the third follow-up (Wave IV), was administered in 2007-2008 to 15,701 of the original Add Health participants (see Harris et al., 2008 for more detailed information on the Add Health data collection strategy).

The Add Health dataset is useful for our purposes because it (i) contains a relatively large sample of military servicemen and women $(\mathrm{N}=1,110)$ at the time of the Wave IV survey, and (ii) provides information on whether active-duty servicemen and women were deployed to a combat zone $(\mathrm{N}=439)$, a non-combat zone outside of the United States $(\mathrm{N}=153)$, or served on active-duty in the United States exclusively $(\mathrm{N}=343)$, and includes information on exposure to specific combat events. ${ }^{5}$ Moreover, because the survey is longitudinal in nature and spans back to adolescence, we have information on the respondent's mental health prior to any military deployment. We restrict our sample to respondents who provided non-missing information on mental health and military service at Wave IV when the respondents were young adults ages 24 and 33 .

\footnotetext{
${ }^{5}$ The remaining 175 individuals are in non-active duty service exclusively in the Reserves or National Guard.
} 
We measure military service in the United States Armed Forces using respondents' reports of active duty service and deployment assignment at Wave IV. ${ }^{6}$ In our sample, 6.0 percent $(\mathrm{N}=935)$ reported active duty military service and 1.1 percent reported non-active duty service exclusively in the Reserves or National Guard $(\mathrm{N}=175){ }^{7}$ Approximately 81 percent of those who reported any military service served during the GWOT, while the remainder served exclusively during the late 1990s when the U.S. was engaged in military operations in the Balkans, including the Kosovo War (Operation Allied Force).

Importantly, the data allow us to distinguish between those who reported active duty service exclusively in the United States, active duty service outside the United States in noncombat zones, and active duty service outside the United States in combat zones. ${ }^{8}$ Among those who report active-duty service, 36.6 percent $(\mathrm{N}=343)$ report service exclusively in the United States, 16.4 percent report service overseas in a non-combat zone $(\mathrm{N}=153)$, and 47.0 percent $(\mathrm{N}$ $=439$ ) report deployment in a combat zone. Among those who served in combat, 93.0 percent reported combat service in the post-9/11 period.

We are also able to measure self-reports of violent combat events experienced by those deployed to combat zones, including the number of "times [they] engaged the enemy in a

\footnotetext{
${ }^{6}$ Service in the Armed Forces was measured using the following Wave IV questionnaire items:

Have you ever served in the military (Possible answers: Yes, No)

In which components of the military have you served? (Possible answers: Active Duty, Reserves, National Guard, None)

${ }^{7}$ The weighted means for military service in the 2008 Add Health are comparable to weighted means in the 2008 Current Population Survey and the 2008 American Community Survey. For instance, in the 2008 ACS, 5.0 percent reported active duty service, as compared to 5.87 percent in Add Health. The unweighted means are slightly larger in the Add Health due to an oversample of racial minorities, who are more likely to serve in the military.

${ }^{8}$ The Wave IV Add Health questionnaire items used to obtain these measures were:
}

Was your military service in the US, outside the US, or both?

What is the total amount of time you (have) served in a combat zone?

The Add Health does not contain information on the country to which the soldier was deployed. 
firefight," whether they "ever kill[ed] or think [they] killed someone," whether they were "wounded or injured" during combat deployment, and whether they saw "anyone wounded, killed, or dead, including 'coalition or ally,' 'enemy,' or 'civilian.'” Among those who served in a combat zone, the average number of enemy firefights was $15.2 ; 36.2$ percent $(\mathrm{N}=159)$ had killed or believed they had killed someone, 11.9 percent $(\mathrm{N}=52)$ were wounded or injured, and 64.7 percent $(\mathrm{N}=284)$ witnessed the death or wounding of an ally, enemy, or civilian.

In the empirical analyses below, we examine the relationship between the above measures of military service and four mental health outcomes measured at Wave IV. The first measure, Suicide, is an indicator of suicidal ideation created using respondents report of whether they had "ever seriously thought about committing suicide during the past 12 months." Respondents who answered in the affirmative were coded as 1 and those who answered in the negative were coded as 0 .

Second, we use an abridged version of the Center for Epidemiological StudiesDepression (CES-D) Scale, originally developed by Radloff (1977) and used widely as a measure of depressive symptomatology. Respondents were instructed to indicate the frequency with which they had experienced certain feelings or emotions during the past week, including being "bothered by things that usually don't bother you," being unable to "shake off the blues, even with help from your family and friends," having "trouble keeping your mind on what you were doing," or feeling "depressed" or "sad." Possible responses, which included "rarely or none of the time" $(=0)$; "some or a little of the time" $(=1)$; "occasionally or a moderate amount of the time" $(=2)$; and "most or all of the time" $(=3)$ were summed to produce a score of between 0 and 15. From this score, we defined an individual as Depressed if he or she is ranked in the top quintile of the distribution of CES-D scale, following a strategy employed by a number 
of researchers (Tekin, Mocan, and Liang, 2009; Tekin and Markowitz, 2008; Chatterji and Cuellar, 2006; Hallfors et al., 2004; Goodman and Capitman, 2000). An advantage of dichotomizing the CES-D score in this manner is that it focuses attention on the right-hand tail of the CES-D distribution, where medical diagnoses of major depression are made. ${ }^{9}$

Our third measure of mental health, Counseling, is generated using the respondent's answer to a question about whether he or she had "received psychological or emotional counseling in the past 12 months." Those who reported having ever received psychological or emotional counseling were coded as 1 and those who had not as 0 . This measure is valuable to the extent that receipt of psychological counseling captures the presence of more severe depressive symptomatology.

Finally, following much of the PTSD literature (Shen et al., 2009ab), we create an indicator, PTSD, for whether the respondent had received a medical diagnosis of post-traumatic stress disorder using responses to the question, "Has a doctor, nurse or other health care provider ever told you that you have or had post-traumatic stress disorder?" Respondents who answered in the affirmative were coded as 1 and those who answered in the negative as 0.

Our final two measures of mental health are useful because they involve doctor treatment or diagnosis of mental health conditions, which may measure psychological problems that are not adequately captured by a self-reported suicide measure or abridged CES-D scale. However, using professional counseling and medical diagnosis measures raises a concern that we may confound mental health conditions with access to health services or screenings. While we control for health insurance status in all models, mental health screenings are increasingly employed among active-duty personnel. For instance, service members are required to complete

\footnotetext{
${ }^{9}$ Using the cutoff preferred by Sabia and Rees (2008) and Duncan and Rees (2005) as well as a self-reported medical diagnostic measure produces qualitatively similar results.
} 
a health assessment, which includes an evaluation of mental health, both before and after deployment (Department of Defense Form 2795). While we do not have a direct measure of access to screenings, for our primary analysis, our treatment and comparison groups are each comprised of deployed active duty personnel or, in some cases, combat soldiers. To the extent that active duty soldiers have comparable access to health care services and screenings, such comparisons should mitigate concerns that we are picking up a unique "screening effect." 10

The means and standard deviations of our dependent variables are presented in Panel A of Table 1 by various measures of military service experience. A comparison of column (2) with columns (3)-(8) generally shows that at Wave IV those who served in the military are in poorer mental health than their civilian counterparts. Moreover, the magnitudes of the differences are larger for those in more stressful missions, such as combat duty or enemy firefights.

In Panel B of Table 1, we show the means of mental health at Wave I prior to any future military service. ${ }^{11}$ We find that those who serve in combat zones later in life have mental health outcomes in adolescence that are no worse, and in some cases better, than their counterparts who remain in civilian life. These findings are consistent with Department of Defense (DOD) enlistment standards described in DOD Directive 6130.3 and DOD Instruction 6130.4, which include screening for mental health problems such as depression and anxiety disorders.

\section{Baseline Results}

\section{OLS Estimates}

\footnotetext{
${ }^{10}$ As a robustness check, we also created a binary indicator for whether the individual has a check-up in the past 12 months or has utilized health care services. Adding these variables as an additional control did not alter any of the results presented below.

${ }^{11}$ Diagnosis of PTSD is not measured at Wave I; thus, this outcome is omitted from Table 1B.
} 
We begin our empirical analyses by estimating an ordinary least squares (OLS) model of the following form:

$$
y_{i}=\alpha+\delta_{1} \text { Active }_{i}+\delta_{2} \text { Non-Active Duty }{ }_{i}+X_{\mathrm{i}} \beta+\varepsilon_{\mathrm{i}}
$$

where $y_{i}$ is one of the mental health outcomes for respondent $i$ and Active $e_{i}$ is an indicator for whether the respondent reported active duty military service, Non-Active Duty is an indicator for non-active duty service in the Reserves or National Guard, and the vector $\mathbf{X}_{\mathbf{i}}$ includes a set of individual and family background characteristics including age, race, ethnicity, gender, measured height, measured weight, years of schooling attained, earnings, physical health, marital status, religiosity, maternal educational attainment, parental marital status when the respondent was an adolescent, parental income when the respondent was an adolescent, an abridged version of the Peabody Picture and Vocabulary Test (PPVT), and health insurance status. The means of each of these control variables, by military status, appears in Appendix Table 1.

OLS estimates of $\delta_{1}$ and $\delta_{2}$ from equation (1) are presented in Panel A of Table 2. ${ }^{12}$ The omitted category is comprised of civilians who had never served in the military. The estimates in Panel A show that those who report active duty service have a 2.0 percentage-point higher probability of suicidal thoughts, a 3.1 percentage-point higher probability of depressive symptomatology, a 4.8 percentage-point higher probability of psychological or emotional counseling receipt, and a 7.8 percentage-point higher probability of PTSD than their civilian counterparts. Those with non-active duty military experience are no more likely to have mental health problems than those who have never served in military, with the exception that they are more likely to have been diagnosed with PTSD.

\footnotetext{
${ }^{12}$ We report standard error estimates that are robust to any form of heteroskedasticity (Angrist and Krueger, 1999), and also cluster on the school. Estimation of the models via probit yielded qualitatively similar marginal effects. The estimated coefficients on the variables in $\mathbf{X}_{\mathrm{i}}$ are consistent with those found in the relevant literature and are available from the authors.
} 
In Panels B to D of Table 2, we present estimates by branch of service. We find the largest and most consistently significant mental health effects of active duty service for the Army (Panel B). For the Navy and Air Force, OLS estimates are much smaller in magnitude.

If, for the moment, we treat the OLS estimate as causal, $\delta_{1}$ can be interpreted as the mental health effect of randomly drafting a civilian into active duty service. However, given that active duty service is endogenous, $\delta_{1}$ is likely to be biased. An alternative contrast that may be more informative is $\delta_{1}-\delta_{2}$, the conditional mean difference in mental health between active duty soldiers and reservists/national guardsmen. This comparison may assure more similarity on unobservables by comparing populations that have each volunteered for some form of military service. Comparing the coefficients on active-duty Army soldiers to national guardsmen and reservists, we find that those on active duty have a $9.0(11.6$ - 2.6) percentage-point higher likelihood of counseling and an 8.7 (13.9 - 8.7) percentage-point higher probability of PTSD. ${ }^{13}$

\section{School and Family Fixed Effects}

One critique of OLS estimates of $\delta_{1}\left(\right.$ and $\left.\delta_{2}\right)$ is that they may capture unobserved community-level characteristics associated with both psychological well-being and active duty service. For instance, youths in economically depressed areas may have worse mental health and face lower opportunity costs of volunteering for active duty service (Brown, 1985; Morrison and Myers, 1998). Moreover, respondents from less socially connected schools may be more likely to join the military and have worse psychological outcomes (Elder et al., 2010). Because of these concerns, we take advantage of the fact that the Add Health data are school-based, and

\footnotetext{
${ }^{13}$ In alternate specifications, we experimented with splitting the civilian population by those who worked in protective services occupations, such as police and firefighting, with those who did not work in such professions. The regression-adjusted difference in the mental health outcomes of active duty soldiers versus civilians employed in protective services is qualitatively similar to that obtained when comparing active-duty personnel to all civilians.
} 
augment equation (1) with school fixed effects (measured at Wave I when the respondent was in junior high or high school) to control for school or community heterogeneity:

$$
y_{i s}=\alpha+\delta_{1} \text { Active }_{i s}+\delta_{2} \text { Non-Active Duty }_{\text {is }}+\mathrm{X}_{\mathrm{is}} \beta+v_{\mathrm{s}}+\varepsilon_{\mathrm{is}} \text {, }
$$

where $v_{\mathrm{s}}$ is a vector of school fixed effects. Panel A of Table 3 presents estimates of $\delta_{1}$ and $\delta_{2}$ from equation (2). Our school fixed effects estimates are remarkably similar to OLS estimates obtained without fixed effects in Panel A of Table 2, suggesting that while youths' neighborhoods and schools may be related to the decision to later join the military, these effects appear to be orthogonal to the relationship between military service and mental health.

Another critique of OLS estimates is that they may be confounded by family background characteristics. For instance, there is evidence that individuals with fewer resources and larger family sizes are more likely to join the military (Kilburn and Asch, 2003; Kilburn and Klerman, 1999), and as noted above, socioeconomic status has also been found to be related to mental health (Miech et al., 1999). Moreover, the enlistment of a parent is associated with a greater expectation and probability of service among offspring (Faris, 1984; Kilburn and Klerman, 1999; Segal and Segal, 2004), suggesting that there may be common familial values associated with military service and psychological well-being. To address the role of family-level unobservables, we restrict the sample to full biological siblings (or twins) and add family fixed effects to equation (1):

$$
y_{i j}=\alpha+\delta_{1} \text { Active }_{i}+\delta_{2} \text { Non-Active Duty }_{i}+\mathrm{X}_{\mathrm{ij}} \beta+\zeta_{\mathrm{j}}+\varepsilon_{\mathrm{ij}},
$$

where $j$ denotes the respondent's family, $\zeta_{\mathrm{j}}$ is a vector of family fixed effects, and $\mathrm{X}_{\mathrm{ij}}$ is a vector of individual characteristics that may vary between siblings, including physical health, height, weight, gender, marital status, age, income, education, health insurance status, and PPVT score. 
In Panels B and C of Table 3, we present estimates of equation (3) for full biological siblings and twins, respectively. Identification comes from 115 discordant pairs of siblings and 42 discordant pairs of twins. Our findings show that controlling for fixed family level unobservables does not diminish the estimated effect of military service on mental health despite the reduced sample size and identifying variation. Across each of our mental health outcomes, we find that active duty military service is positively related to depression, suicide, psychological counseling, and PTSD. We find that respondents who serve on active duty have a greater risk for PTSD than their siblings serving in the military in non-active duty roles.

\section{Exploiting Variation in Deployment Assignment}

Comparing active duty military personnel with their civilian schoolmates, siblings, and non-active duty military counterparts is informative in the sense that we can rule out some important forms of heterogeneity bias. However, these estimates are ultimately unsatisfying in identifying causal effects because of unobserved individual heterogeneity that may be associated with selection into active duty service. While the absence of a draft precludes its use a source of exogenous variation in military service, we instead focus on active duty soldiers and explore whether those who are assigned to combat duties experience worse mental health outcomes than their active duty counterparts assigned to non-combat duties. This approach will identify the effect of exogenous assignments to combat relative to non-combat duties assignments. We begin by estimating:

$$
\begin{gathered}
y_{i s}=\alpha+\delta_{1} \text { Combat }_{i s}+\delta_{2} \text { Non-Active Duty } y_{i s}+\delta_{3} \text { Active Non-Combat OUS } \text { is }_{\text {is }}+\delta_{4} \text { Active } \\
\text { Non-Combat } U S_{\text {is }}+X_{\text {is }} \beta+v_{\mathrm{s}}+\varepsilon_{\text {is }},
\end{gathered}
$$


where Combat indicates active-duty service outside the U.S. in a combat zone, Active NonCombat OUS is indicates active-duty service outside the U.S. in a non-combat zone, and Active Non-Combat $U S_{i s}$ indicates active-duty service exclusively in the United States.

The central focus of our attention in equation (4) is on the contrast $\delta_{1}-\delta_{3}$. As noted above, if deployment assignments are exogenous, then ${\hat{\delta_{1}}}-\hat{\delta_{3}}$ can be interpreted as the causal effect of combat service net of deployment (Lyle 2006; Engel et al., 2010). The descriptive evidence in our data is consistent with this hypothesis. In column (1) of Appendix Table 2, we restrict our sample to those for whom Combat $O U S_{i s}=1$ or Active Non-Combat $O U S_{i s}=1$, and regress an indicator of whether the soldier served in combat on our set of observables. Of our 33 main right-hand side variables, which include a wide set of family and individual background characteristics, 32 had associations that were statistically indistinguishable from zero, consistent with the hypothesis that deployment assignment was exogenous to mental health. ${ }^{14}$

In Table 4, we present estimates of equation (4). We find that combat zone experience is associated with an $8.6(9.6-1.0)$ percentage-point higher probability of psychological counseling and $14.2(15.0-0.8)$ percentage-point higher probability of PTSD relative to active duty service outside the United States in non-combat zones. Rates of suicidal thoughts and depression, however, are statistically equivalent between these groups.

While our theoretical justification for the exogeneity of deployment assignments and presentation of evidence on the similarities (on observables) between combat and non-combat soldiers are informative, the richness of our data provides a further way to guard against the possibility that deployment assignments are correlated with unmeasured traits of soldiers that are related to mental health. Specifically, we take advantage of the longitudinal nature of the Add

\footnotetext{
${ }^{14}$ Only the "other" race category was a significant predictor of combat; we control for this race category in all models.
} 
Health data to control for mental health of the respondent at Wave I when the respondents were attending school in grades 7 through 12:

$$
\begin{aligned}
& y_{\text {is }}=\alpha+\pi y_{\text {ist- } 3}+\delta_{1} \text { Combat }_{\text {is }}+\delta_{2} \text { Non-Active Duty }_{i s}+\delta_{3} \text { Active Non-Combat OUS }_{\text {is }}+ \\
& \delta_{4} \text { Active Non-Combat } U S_{i s}+X_{\text {is }} \beta+v_{\mathrm{s}}+\varepsilon_{\text {is }}
\end{aligned}
$$

where $t$ corresponds to Wave IV and $t-3$ corresponds to Wave I. ${ }^{15}$

The findings from equation (5) in Panel A of Table 5 show that active duty service in a combat zone is associated with an 8.1 percentage-point increase in the probability of emotional counseling and a 14.5 percentage-point increase in probability of PTSD relative to the change in these outcomes by active duty counterparts serving in non-combat outside the United States. These estimates are remarkably similar to those shown in the Panel A of Table 4, which do not control for lagged mental health, providing further evidence in support of our hypothesis that deployment assignment is exogenous to traits of soldiers that are fixed over time. ${ }^{16}$

An alternative way to remove time-invariant unobserved heterogeneity is through an individual fixed effects model. In Panel B of Table 5, we show fixed effects models, estimated via first differences, for the three mental health outcomes we observe in both Waves I and IV (suicidal thoughts, depressive symptomatology, and emotional counseling), controlling for timevarying observables. These estimates, identified by those who volunteer for service between Waves I and IV, are remarkably similar to those presented in earlier tables.

In a further effort to ensure that our comparisons of combat soldiers with non-combat soldiers serving outside the United States captures similar types of soldiers, we restrict the

\footnotetext{
${ }^{15}$ While 84.4 percent of respondents were younger than age 18 at Wave I, 30 respondents $(0.2$ percent $)$ reported military service at Wave I. To ensure that $\mathrm{y}_{\text {ist-3 }}$ captures pre-military mental health, we drop these 30 individuals from our sample. However, the results are qualitatively similar with their inclusion. Because we do not have a measure of PTSD at Wave I, our estimates from equation (5) include receipt of emotional or psychological counseling as our pre-deployment dependent variable.

${ }^{16}$ As another descriptive test of the plausible exogeneity of deployment assignment, Appendix Table 3 shows the strong stability of the estimated contrast $\delta_{1}-\delta_{3}$ to a wide set of controls for individual and family characteristics.
} 
sample to those who had served in the military, and add controls for military rank, timing of service in the military, branch of service, and occupation (four-digit Standard Occupational Classification code) to the vector $\mathbf{X}_{i}$. We also add a control for whether the respondent had a medical checkup in the last year to control for propensity to use medical services, and continue to control for pre-deployment mental health. These characteristics, along with those previously included in $\mathbf{X}_{i}$ capture soldiers' characteristics that are available to U.S. military personnel at Human Resources Command when making deployment decisions (Engel et al., 2010). ${ }^{17}$ Panel A of Table 6 presents our findings using these additional controls; the omitted category is comprised of military personnel on non-active duty. The results in Panel A from our preferred specification show that those serving in combat are 7.3 percentage-points more likely to obtain psychological or emotional counseling and 12.1 percentage-points more likely to have been diagnosed with PTSD than their active duty counterparts in non-combat zones outside the U.S. ${ }^{18}$

Finally, in Panels B and C of Table 6 , we test the robustness of our estimates of $\delta_{1}-\delta_{3}$ in Panel A to more similar comparison groups. We restrict our sample to those who served in the Army (Panel B) and to those who served in the Army in the post-9/11 period (Panel C). Our findings in each of these panels continue to show that assignment to combat is associated with substantial adverse mental health effects. Individual fixed effects estimates on the Army sample (Panel D) and the Army post-9/11 sample (Panel E) show a similar pattern of results. ${ }^{19}$

\footnotetext{
${ }^{17}$ Military-specific occupations were measured with respect to the respondent's job last year at Wave IV. The categories include Military Officer Special and Tactical Operations Leaders/Managers, Infantry Officers, Special Forces, Armored Assault Vehicle Officers, Artillery and Missile Officers, Air Crew Officers, Command and Control Center Officers, and First-Line Enlisted Military Supervisors/Managers, and Radar and Sonar Technicians. Occupations in engineering and medicine are measured in similar detail.

${ }^{18}$ When we add pre-deployment CES-D and suicidal thoughts to the PTSD equation, the marginal effect remains stable. Moreover, in unreported results, we find no difference in the mental health effects of combat by gender.

${ }^{19}$ It may also be that the mental health effects of deployment differ by marital status. In results that are available upon request, we descriptively explore this question. We find that the adverse effects of combat deployment are slightly larger in magnitude for married as opposed to unmarried soldiers.
} 


\section{The Effect of Combat Events on Mental Health}

The existing literature on the mental health effects of combat service in the GWOT have focused on the effects of deployment length (Buckman et al., 2010; Shen et al., 2009a,b; Rona et al., 2007). In Table 7, we replicate their findings using the Add Health. We restrict the sample to those with combat zone experience ${ }^{20}$ and control for the augmented vector $\mathbf{X}_{\mathrm{i}}$, which includes school fixed effects, military rank, branch of service, timing of service, occupation, and predeployment mental health. Consistent with Shen et al. (2009b) and Adler et al. (2005), our results show that those serving more than 12 months in a combat zone experience an 12.9 percentage-point higher probability of receiving a PTSD diagnosis than those with combat zone service of 1 to 6 months, and a 14.3 percentage-point higher probability of PTSD than those who serve for one year or less.

However, an important question remains: Does deployment length adversely affect soldiers' mental health or is it psycho-traumatic violent combat events often associated with longer deployments? To explore this question, we exploit a unique aspect of the Add Health data, which include information on enemy firefighting and death-related experiences among those who had deployed to a combat zone. Such experiences vary by combat deployment assignment, which we argue above is exogenously assigned. In column (2) of Appendix Table 2, we find that assignment to a frequent enemy fire combat zone is unrelated to observable family or individual characteristics of soldiers. ${ }^{21}$ In Panel A of Table 8, we present estimates of the mental health effects of experiencing enemy firefight. We find that those who experience enemy firefight have a 10.4 percentage-point higher probability of suicidal ideation, an 11.2 percentage-point higher probability of receiving psychological counseling, and an 18.3 percentage-point higher

\footnotetext{
${ }^{20}$ This approach has the advantage of ensuring common health services/screenings among those assigned to combat. ${ }^{21}$ Only being male is marginally positively related to the probability of enemy firefight. When we replicate Panel A of Table 8 on a sample of males, our results are qualitatively and quantitatively similar.
} 
probability of PTSD. In Panel B, we examine whether those who engage more frequently in enemy firefight suffer adverse psychological consequences. Our chosen specification divides the frequency distribution of those who experienced enemy firefights in thirds. We find that those who reported 20 or more engagements with enemy firefight had the largest adverse psychological effects.

In Panel C of Table 8, we replicate the analysis in Panel A, but add controls for deployment length. The results show that those who engage in more frequent enemy firefights are at a greater risk for suicidal thoughts, depression, counseling, and PTSD than their counterparts who face fewer combat firefights, although the coefficient on counseling is not precisely estimated. Given that deployment assignments of combat units depend on military need and readiness of the unit rather than characteristics of individual soldiers, the frequency of enemy firefight can be thought of as exogenous to mental health and our estimates interpreted causally. Interestingly, we find that the effect of deployment length is substantially diminished after conditioning on number of enemy firefights and none of the deployment length effects are statistically significant at conventional levels. This suggests that frequent enemy firefight drives the adverse psychological consequences previously attributed to combat deployment length. ${ }^{22}$

In Table 9, we examine the effects of deaths and injuries on mental health, conditional on deployment length. In Panel A, we find that those serving in combat zones who had killed (or believed they had killed) someone experienced an 12.0 percentage-point increase in the probability of suicidal thoughts, a 13.0 percentage-point increase in the probability of depressive symptomatology, and a 22.2 percentage-point higher probability of PTSD than those who did not believe they had killed another. In Panel B, we find that being wounded or injured in combat is

\footnotetext{
${ }^{22}$ Cross-tabulations show that there is some independent variation between frequency of enemy firefighting and mental health. For example, among those who deployed for more than 12 months 62.6 percent experienced fewer than five firefights. Among those who deployed less than 12 months, 16.7 percent reported five or more firefights.
} 
associated with a 18.4 percentage-point increase in the probability of depressive symptomatology, a 27.5 percentage-point increase in the probability of psychological counseling, and a 23.9 percentage-point higher probability of PTSD.

In Panel C, we explore whether observing someone wounded, killed, or dead affects soldiers' mental health. Because respondents were permitted to choose multiple categories among "coalition or ally," "enemy," "civilian," or "none", in Panel C, we enter these nonmutually exclusive categories on the right hand-side of the estimating equation. The results suggest that seeing a coalition/ally member or civilian killed, dead, or wounded has adverse psychological consequences for those serving in combat zones. However, we find that observing the killing, death, or wounding of the enemy has no independent adverse psychological consequences. Despite limited power in these models, each of the coefficients for those who saw wounded enemy are very close to zero in magnitude. This finding is consistent with the hypothesis that strong feelings of guilt may accompany the death of non-combatants or friends.

Finally, in Table 10, we replicate the estimates in Table 9, conditional on number of enemy firefights so as to compare those who have served in combat zones for similar lengths of time and who have experienced a similar number of enemy firefights. The pattern of results in Panel A suggests that the estimated mental health effect of killing someone in battle can largely be explained by number of enemy firefights. However, even after conditioning on number of firefights, we continue to find that being injured or wounded in combat and observing the death or wounding of a civilian non-combatant are significantly positively associated with PTSD. Finally, we find no independent effect of combat deployment length after controlling for frequency of enemy firefight. 


\section{Conclusion}

The U.S. military has engaged in two wars in Iraq and Afghanistan in the last ten years, deploying 2.16 million U.S. troops since October 2001 (Department of Defense, 2010a). As of March 10, 2010, 4,658 U.S. soldiers had been killed in action, 42,593 had been wounded in action, and many more returning home with "invisible wounds," such as mental health injuries (Department of Defense, 2010b). In this study, we provide the first set of credible estimates of the causal effect of combat service on young adults' psychological well-being. We pay attention to the role of unmeasured heterogeneity by controlling for mental health prior to deployment and exploiting plausibly exogenous variation in deployment assignment and exposure to violent combat events.

The results of this study lend support to the hypothesis that combat service is associated with mental health problems and that the mechanism is driven by potentially psycho-traumatic incidences experienced during combat zone missions. In particular, we find that frequent enemy firefight, wounding or injury, and observing the death or wounding of a coalition/ally or non-combatant is associated with a substantial increase in the risk of suicidal thoughts and PTSD.

The U.S. Army recently announced plans to reduce combat zone deployments to nine months and to increase the time between deployments to three years by the year 2014 (Tice, 2010). While our findings confirm that deployment length is associated with declines in mental health, our results also show that this effect is driven by frequent enemy firefight rather than deployment length alone. Thus, military policymakers crafting optimal deployment schedules that account for mental health problems of soldiers should focus greater attention on violent combat events rather than simply 
soldiers' time spent in a combat zone. Moreover, our findings suggest that reducing soldiers' exposure to civilian casualties in battle may also avert substantial adverse mental health consequences for US soldiers.

To put the magnitudes of our estimates into perspective, we consider a crude translation of the marginal effects measured in this paper into dollar terms, using estimates of the costs of PTSD from the literature. Tanielian and Joycox (2008) estimate the two-year, per-person, health care cost of PTSD to be between $\$ 5,904$ and $\$ 10,298$. Our preferred marginal effect of combat-induced PTSD from Panel A of Table 6 is 0.121 . Then, an estimate of the two-year total costs of PTSD can be calculated by multiplying our marginal effect by the 2.16 million U.S. troops deployed in combat zones in Iraq and Afghanistan since 2001, and by the per-person cost estimate provided by Tanielian and Jaycox (2008) to obtain a total health care cost estimate of $\$ 1.54$ to $\$ 2.69$ billion for combat-induced PTSD. The largest share of these health care costs appears to be generated by those in combat who experience greatest enemy firefight, are wounded, or observe the death of non-combatants or coalition/ally soldiers.

It is important to keep in mind that our cost estimates are lower-bound estimates of health care costs because they represent costs only for younger soldiers measured in the short-run. Moreover, our costs do not capture the effects of combat-induced adverse mental health on future labor market, marriage, and other socioeconomic outcomes ${ }^{23}$ Future research that follows soldiers as they transition back into civilian life will be able to provide further information on the longer-run effects of combat service in the GWOT.

\footnotetext{
${ }^{23}$ In the civilian context, depression and psychological impairment have been found to be associated with crime, lower socioeconomic status, diminished educational attainment, and a grascheater propensity for marital problems (Ettner et al., 1997; Kessler et al., 1998, 2000; Fletcher, 2010; Fazel and Grann, 2006; Tekin and Markowitz, 2008; Fletcher, 2010).
} 


\section{References}

Adler AB, Huffman AH, Bliese PD, Castro CA. 2005. "The impact of deployment length and experience on the well-being of male and female soldiers. J Occup Health Psychol. Apr;10(2):121-37.

Angrist, Joshua D. \& Krueger, Alan B., 1999. "Empirical strategies in labor economics," Handbook of Labor Economics, in: O. Ashenfelter \& D. Card (ed.), Handbook of Labor Economics, edition 1, volume 3, chapter 23, pages 1277-1366 Elsevier.

Angrist, Josh and John Johnson. 2000. "Effects of Work-Related Absences on Families: Evidence from the Gulf War," Industrial and Labor Relations Review 54(1): 41-58.

Angrist, Joshua D., Stacey H. Chen, and Brigham R. Frandsen. 2010. "Did Vietnam Veterans get Sicker in the 1990s? The Complicated Effects of Military Service on SelfReported Health." Forthcoming in the Journal of Public Economics.

Autor, David, Mark G. Duggan, and David S. Lyle. 2011. "Battle Scars? The Puzzling Decline in Employment and Rise in Disability Receipt among Vietnam Era Veterans," Forthcoming in the American Economic Review Papers and Proceedings.

Bachman, Jerald G., David R. Segal, Peter Freedman-Doan, and Patrick M. O’Malley. 2000. "Who Chooses Military Service? Correlates of Propensity and Enlistment in the U.S. Armed Forces.' Military Psychology 12(1):1-30.

Bedard, Kelley and Olivier Deschenes. 2004. "The Long-Term Impact of Military Service on Health: Evidence from World War II and the Korean War," American Economic Review 96(1): 176-194.

Buckman, Joshua E J, 'Josefin Sundin, Talya Greene,' Nicola T Fear,Christopher Dandeker, Neil Greenberg, Simon Wessely. 2010. "The impact of deployment length on the health and wellbeing of military personnel: a systematic review of the literature." Occup Environ Med, September.

Brown, Charles. 1985. "Military Enlistments: What Can We Learn from Geographic Variation?" American Economic Review 75(1): 228-234.

Bryant, R.A. and R.M. Guthrie. 2005. "Maladaptive Appraisals as a Risk Factor for PostTraumatic Stress: A Study of Trainee Firefighters," Psychological Science 16: 749-752.

Bryant, R.A. and R.M. Guthrie. 2007. "Maladaptive Self-Appraisals Before Trauma Exposure Predict Post-Traumatic Stress Disorder," Journal of Consulting and Clinical Psychology 75: 812-815.

Card, J. 1987. "Epidemiology of PTSD in a National Cohort of Vietnam Veterans," Journal of Clinical Psychology 43: 6-17. 
Chatterji, Pinka, and Alison Cuellar. 2006. "How Do Youth With Mental Disorders Fare in the Juvenile Justice System.” NBER Working Paper \#12437, August.

Department of Defense. 2010a. "Legal Residence/Home Address for Service Members Ever Deployed as of July 30, 2010," CTS Deployment File, Available at:

http://dva.state.wi.us/WebForms/Data Factsheets/ResDistribution Jul10.pdf

Department of Defense. 2010b. Daily Updated Casualty and Wounding Data. Available at: http://www.defense.gov/news/casualty.pdf.

Department of Defense Directive 6130.3. "Physical Standards for Appointment, Enlistment and Induction," Available at: http://biotech.law.lsu.edu/blaw/dodd/corres/html/61303.htm

Department of Defense Directive 6130.4 "Criteria and Procedure Requirements for Physical Standards for Appointment, Enlistment, or Induction in the Armed Forces," Available at: http://biotech.law.lsu.edu/blaw/dodd/corres/html/61304.htm

Department of Defense Form 2795. "Pre-Deployment Health Assessment," Available at: http://www.dtic.mil/whs/directives/infomgt/forms/eforms/dd2795.pdf

Dobkin, Carlos and Reza Shabani. 2009. "The Health Effects of Military Service: Evidence from the Vietnam Draft," Economic Inquiry 47(1): 69-80.

Duncan, Brian and Daniel I. Rees. 2005. "The Effect of Smoking on Depressive Symptomatology: A Reexamination of the Data from the National Longitudinal Study of Adolescent Health," American Journal of Epidemiology 162(5): 461-470.

Edwards, Ryan D. and Alair MacLean. 2010. "Military Service, Combat Exposure, and Health in Retirement," Working Paper, Queens College.

Elder, Glen Jr., Lin Wang, Naomi Spence, Daniel E. Adkins, and Tyson H. Brown. 2010.

"Pathways to the All-Volunteer Military," Social Science Quarterly vol. 91, issue 2.

Engel, Rozlyn C., Luke B. Gallagher, and David S. Lyle. 2010. "Military Deployments and Children's Academic Achievement: Evidence from Department of Defense Education Activity Schools," Economics of Education Review 29(1): 73-82.

Erbes, C.J. Westermeyer, B. Engdahl, and E. Johnsen. 2007. "Post-Traumatic Stress Disorder and Service Utilization in a Sample of Service Members from Iraq and Afghanistan," Military Medicine 172(4): 359-363.

Ettner, Susan L, Richard G. Frank and Ronald C. Kessler. 1997. "The Impact of Psychiatric Disorders on Labor Market Outcomes," Industrial and Labor Relations Review 51(1). 
Faris, J.H. 1984. ' Economic and Noneconomic Factors of Personnel Recruitment and Retention in the AVF,' Armed Forces \& Society 10(2):251-75.

Fazel S, Grann M. 2006. “The population impact of severe mental illness on violent crime," Am J Psychiatry, 163(8):1397-1403.

Fletcher, Jason. 2010. "Adolescent Depression and Educational Attainment: Evidence from Sibling Fixed Effects," Health Economics 19(7) 855-871.

Goodman, Elizabeth, and John Capitman. 2000. "Depressive Symptoms and Cigarette Smoking Among Teens.” Pediatrics 106(4): 748-755.

Hallfors, Denise D., Martha W. Waller, Carol A. Ford, Carolyn T. Halpern, Paul Brodish, and Bonita Iritani. 2004. "Adolescent Depression and Suicide Risk: Association with Sex and Drug Behavior.” American Journal of Preventative Medicine 27(3): 224-231.

Harris, Kathleen Mullan, Carolyn Tucker Halpern, Pamela Entzel, Joyce Tabor, Peter S. Bearman, and J. Richard Udry. 2008. The National Longitudinal Study of Adolescent Health: Research Design.

Hearst, N., T.B. Newman, and S.B. Hulley. 1986. "Delayed Effects of the Military Draft on Mortality: A Randomized Natural Experiment," New England Journal of Medicine 314(10): 620624.

Heinrichs, M., D. Wagner, W. Schoch, L.M. Soravia, D.H. Hellhammer, and U. Ehlert. 2005. "Predicting Post-Traumatic Stress Symptoms from Pre-Traumatic Risk Factors: A Two-Year Prospective Follow-Up Study in Firefighters," American Journal of Psychiatry 162: 2276-2286.

Hoge, C., J.L. Auchterlonie et al. 2006. "Mental Health Problems, Use of Mental Health Services, and Attrition from Military Service After Returning from Deployment to Iraq or Afghanistan," Journal of the American Medical Association 295(9): 1023-1032.

Hoge, C., C.A. Castro et al. 2004. "Combat Duty in Iraq and Afghanistan: Mental Health Problems and Barriers to Care," New England Journal of Medicine 317(26): 1630-1634.

Iowa Persian Gulf Study Group. 1997. "Self-Reported Illness and Health Status Among Gulf War Veterans. A Population-Based Study. The Iowa Persian Gulf Study Group," Journal of the American Medical Association 277(3): 238-245.

Jordan, B. K., W. E. Schlenger, R. Hough, R. A. Kulka, D. Weiss, J. A. Fairbank, and C. R. Marmar. 1991. "Lifetime and Current Prevalence of Specific Psychiatric Disorders among Vietnam Veterans and Control," Archives of General Psychiatry 48: 916-26.

Kang, H. K., and T. A. Bullman. 2001. "Mortality among US Veterans of the Persian Gulf War: 7-Year Follow-up.” American Journal of Epidemiology 154(5): 399-405. 
Kessler RC, Walters EE, Forthofer MS. 1998. "The social consequences of psychiatric disorders, III: probability of marital stability. Am J Psychiatry 155(8):1092-6.

Kessler RC. 2000. "Posttraumatic stress disorder: the burden to the individual and to society. $J$ Clin Psychiatry 61(5):4-12.

Kilburn, M. Rebecca, and Jacob Alex Klerman. 1999. "Enlistment Decisions in the 1990s:

Evidence from Individual-Level Data," Santa Monica, CA: RAND.

Kilburn, M. Rebecca, and Beth J. Asch. 2003. "Recruiting Youth in the College Market: Current Practices and Future Policy Options," Rand Corporation, National Defense Research Institute (U.S.).

Kleykamp, Meredith A. 2006. “College, Jobs, or the Military? Enlistment During a Time of War." Social Science Quarterly 87(2).

Liberman, A.M., S.R. Best, T.J. Meltzer, J.A. Fagan, D.S. Weiss, and C.R. Marmar. 2002. "Routine Occupational Distress in Police," Policing: An International Journal of Police Strategies and Management 25: 421-441.

Lyle, David S. 2006. "Using Military Deployments and Job Assignments to Estimate the Effect of Parental Absences and Household Relocations on Children's Academic Achievement," Journal of Labor Economics 24(2): 319-350.

McFall, M. E., P. W. Mackay, and D. M. Donovan. 1992. "Combat-Related Posttraumatic Stress Disorder and Severity of Substance Abuse in Vietnam Veterans,', Journal of Studies on Alcohol 53: $357-63$.

McKinney, W. P., D. D. Mclntire, T. J. Carmody, and A. Joseph. 1997. "Comparing the Smoking Behavior of Veterans and Non-Veterans," Public Health Report 112: 212-17.

Miech, Richard A., Avshalom Caspi, Terrie E. Moffitt, Bradley R. Entner, and Phil A. Silva. 1999. "Low Socioeconomic Status and Mental Disorders: A Longitudinal Study of Selection and Causation during Young Adulthood," The American Journal of Sociology 104(4): 1096-1131.

Morrison, Donna R. and David E. Myers. 1998. "Factors Influencing the Enlistment Aspirations and Decisions of Hispanic, Black, and White Male Youth," U.S. Army Research Institute for the behavioral and Social Sciences.

National Priorities Project. 2008. Military Recruitment 2008: A Look at Age, Race, Income, and Education of New Soldiers. Available at http://nationalpriorities.org/en/publications/2009/armyrecruitment-in-fy-2008-a-look-at-age-race-inc/ 
Obama, Barack. 2010. "Weekly Address: President Obama Announces Changes to Help Veterans with PTSD Receive the Benefits They Need". Office of the Press Secretary. Retrieved January 14, 2010 from http://www.whitehouse.gov/the-press-office/weeklyaddress-president-obama-announces-changes-help-veterans-with-ptsd-receive-be

Price, R. K., N. K. Risk, A. H. Haden, C. E. Lewis, and E. L. Spitznagel. 2004. "Post-Traumatic Stress Disorder, Drug Dependence, and Suicidality among Male Vietnam Veterans with a History of Heavy Drug Use," Drug and Alcohol Dependence 76S: 31-43.

Radloff, Lenore S. 1977. "The CES-D Scale: A Self-Report Depression Scale for Research in the General Population.” Applied Psychological Measurement 1: 385-401

Rohlfs, Christopher. 2010. "Does Combat Exposure Make You a More Violent or Criminal Person? Evidence from the Vietnam Draft." Journal of Human Resources 45(2): 271-300.

Rona, Roberto J., Lisa Hull, Mark Earnshaw, Simon Wessely. 2007. "Mental Health Consequences of Overstretch in the UK Armed Forces: First Phase of a Cohort Study," British Medical Journal 335(7620): 603-610.

Rosenheck, R.A. and A.F. Fontana. 2007. "Recent Trends in VA Treatment of PostTraumatic Stress Disorder and Other Mental Disorders," Health Affairs 26(6): 17201727.

Sabia, Joseph J. and Daniel I. Rees. 2008. "The Effect of Adolescent Virginity Status on Psychological Well-Being," Journal of Health Economics 27(5): 1368-1381.

Seal, K.H., D. Bertenthal, S. Sen, and C. Marmar. 2007. "Bringing the War Back Home: Mental Health Disorders Among 103,788 US Veterans Returning from Iraq and Afghanistan Seen at Department of Veterans Affairs Facilities," Archives of Internal Medicine 167(5): 476-482.

Segal, David R., and Mady Weschler Segal. 2004. “America's Military Population.” Population Bulletin, vol. 59, no. 4, December.

Segal, David R, Thomas J. Burns, Michael P. Silver, William W. Falk, and Bam Dev Sharda. 1998. "The All-Volunteer Force in the 1970s," Social Science Quarterly 79: 390-411.

Shen, Yu-Chu, Jeremy Arkes, MAJ John Pilgrim. 2009a. "The Effects of Deployment Intensity on Post-Traumatic Stress Disorder: 2002-2006." Military Medicine 174(3): 217223.

Shen, Yu-Chu, Jeremy Arkes, Boon Wah Kwan, Lai Yee Tan, and Thomas V. Williams. 2009b. "The Effect of OEF/OIF Deployment Intensity on the Rate of Post-Traumatic Stress Disorder Among Active Duty Population," NBER Working Paper 15203, Cambridge, MA. 
Tanielian T. and L.H. Jaycox. 2008. "Invisible Wounds of War: Psychological and Cognitive Injuries, Their Consequences, and Services to Assist Recovery," Rand Corporation.

Tekin, Erdal, and Sara Markowitz. 2008. ““"The Effects of Suicidal Behavior on Productive Activities of Young Adults," Southern Economic Journal, 75(2), 300-331, October.

Tekin, Erdal, Naci H. Mocan, and Lan Liang. 2009 "Do Adolescents with Emotional or Behavioral Problems Respond to Tobacco Control Policies?" Southern Economic Journal, vol. 76(1) pages 67-85, July.

Tice, Jim. 2010. “Army considers shorter deployments.” USA Today.

Thompson, Mark. 2010. "Invisible Wounds: Mental Health and the Military." Time.

Wang, Zhen, Sabra S. Inslicht, Thomas J. Metzler, Clare Henn-Haase, Shannon E. McCaslin, Huiqi Tong, Thomas C. Neylan, and Charles R. Marmar. 2010. "A Prospective Study of Predictors of Depression in Police," Psychiatry Research 175: 211-216. 
Table 1: Descriptive Statistics of Mental Health Outcomes by Military Service

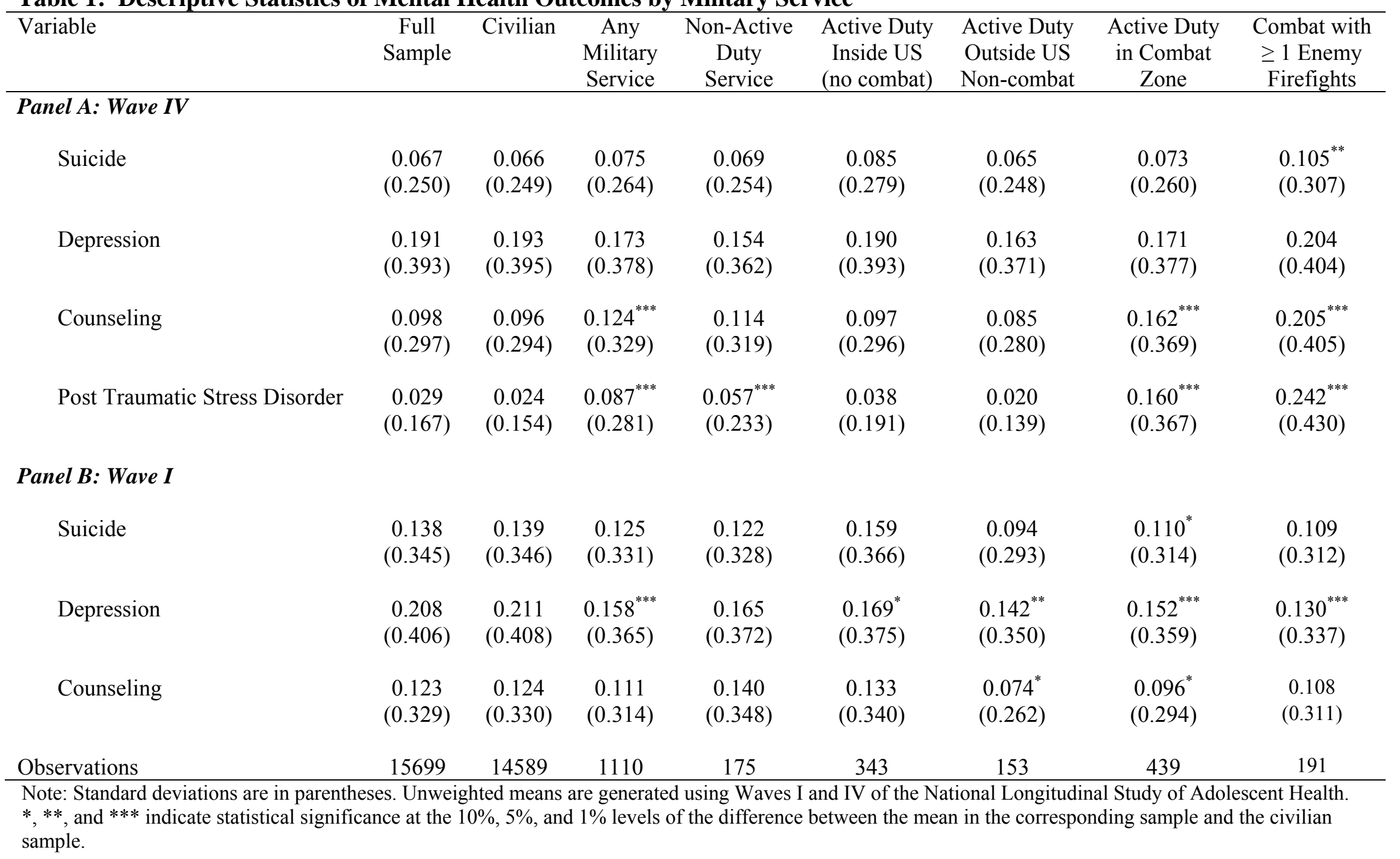


Table 2: OLS Estimates of the Relationship between Military Service and Mental Health, by Branch

\begin{tabular}{lcccc}
\hline & Suicide & Depression & Counseling & PTSD \\
\hline Panel A: All & & & & \\
Active Duty Military Service & $0.020^{* *}$ & $0.031^{* *}$ & $0.048^{* * *}$ & $0.078^{* * *}$ \\
& $(0.010)$ & $(0.014)$ & $(0.011)$ & $(0.008)$ \\
Non-Active Duty Military Service & 0.012 & 0.003 & 0.031 & $0.040^{* *}$ \\
& $(0.020)$ & $(0.029)$ & $(0.023)$ & $(0.018)$ \\
$\widehat{\delta}_{\text {active duty }}-\widehat{\delta}_{\text {no active duty }}=$ 0? [p-value on F-test] & $0.008[0.72]$ & $0.028[0.41]$ & $0.017[0.51]$ & $0.038^{*}[0.05]$ \\
Observations & & & & 15,0596 \\
\hline
\end{tabular}

\section{Panel B: Army}

Active Duty Military Service

$\begin{array}{cccc}0.043^{* * *} & 0.055^{* *} & 0.116^{* * *} & 0.139 * * * \\ (0.016) & (0.024) & (0.019) & (0.018) \\ 0.020 & 0.006 & 0.026 & 0.052 * * \\ (0.025) & (0.035) & (0.026) & (0.022)\end{array}$

$\widehat{\delta}_{\text {active duty }}-\widehat{\delta}_{\text {no active duty }}=0 ?[\mathrm{p}$-value on F-test $]$

$0.023[0.45]$

$0.049[0.30]$

$0.090^{* *}[0.01]$

$0.087^{* * *}[0.00]$

Observations

14,992

15,087

15,093

15,094

\section{Panel C: Navy}

Active Duty Military Service

$\begin{array}{cccc}-0.007 & -0.029 & -0.012 & 0.024^{*} \\ (0.013) & (0.020) & (0.017) & (0.013) \\ 0.037 & -0.050 & 0.010 & -0.023^{* * *} \\ (0.099) & (0.126) & (0.086) & (0.008)\end{array}$

Non-Active Duty Military Service

(0.099)

$(0.126)$

$(0.086)$

(0.008)

$\widehat{\delta}_{\text {active duty }}-\widehat{\delta}_{\text {no active duty }}=0 ?$ [p-value on F-test $]$

$-0.044[0.66]$

$0.039[0.88]$

$-0.022[0.80]$

$0.047^{* * *}[0.03]$

Observations

14,734

14,828

14,836

14,836

\section{Panel D: Air Force}

Active Duty Military Service

$\begin{array}{cccc}0.006 & 0.048 & -0.011 & 0.034^{* *} \\ (0.020) & (0.030) & (0.021) & (0.015) \\ -0.003 & 0.004 & 0.183 & -0.017 * * * \\ (0.050) & (0.078) & (0.111) & (0.005)\end{array}$

No n-Active Duty Military Service

$$
(0.050)
$$

(0.078)

$(0.111)$

$(0.005)$

$\widehat{\delta}_{\text {active duty }}-\widehat{\delta}_{\text {no active duty }}=0 ?$ [p-value on F-test $]$

$0.009[0.85]$

$0.044[0.61]$

$-0.194^{*}[0.08]$

$0.051^{* * *}[0.00]$

Observations

14,659

14,752

14,760

14,760

Robust standard errors corrected for clustering on the school are in parentheses. ${ }^{*}, * *$, and $* * *$ indicate statistical significance at the $10 \%, 5 \%$, and $1 \%$ levels, respectively. All models use the full set of controls shown in Appendix Table 1. Models also include missing dummy categories for each of the control variables. 
Table 3: School and Family Fixed Effects Estimates of the Relationship between Military Service and Mental Health

\begin{tabular}{lcccc}
\hline & Suicide & Depression & Counseling & PTSD \\
\hline Panel A: School Fixed Effects & & & & \\
& & & & \\
Active Duty Military Service & $0.022^{* *}$ & $0.029 * *$ & $0.053^{* * *}$ & $0.079^{* * *}$ \\
& $(0.010)$ & $(0.014)$ & $(0.011)$ & $(0.009)$ \\
Non-Active Duty Military Service & 0.011 & 0.002 & 0.034 & $0.042 * *$ \\
& $(0.021)$ & $(0.029)$ & $(0.022)$ & $(0.018)$ \\
$\widehat{\delta}_{\text {active duty }}-\widehat{\delta}_{\text {no active duty }}=0 ?$ [p-value on F-test] & $0.011[0.67]$ & $0.027[0.43]$ & $0.019[0.48]$ & $0.037 *[0.06]$ \\
Observations & 15,593 & 15,689 & 15,695 & 15,696 \\
\hline
\end{tabular}

Panel B: Family Fixed Effects on Siblings Sample

\begin{tabular}{lcccc} 
Active Duty Military Service & 0.038 & 0.076 & 0.058 & $0.106^{* * *}$ \\
& $(0.035)$ & $(0.049)$ & $(0.042)$ & $(0.031)$ \\
Non-Active Duty Military Service & 0.052 & 0.013 & 0.101 & -0.088 \\
& $(0.083)$ & $(0.080)$ & $(0.069)$ & $(0.058)$ \\
$\hat{\delta}_{\text {active duty }}-\widehat{\delta}_{\text {no active duty }}=0$ ? [p-value on F-test] & $-0.014[0.87]$ & $0.063[0.47]$ & $-0.043[0.57]$ & $0.194^{* * *}[0.00]$ \\
Observations & 2,649 & 2,657 & 2,658 & 2,658 \\
\hline
\end{tabular}

Panel C: Family Fixed Effects on Twins Sample

Active Duty Military Service

$0.138 * *$

$0.159 * *$

0.046

$(0.066)$

$(0.068)$

(0.071)

(0.046)

Non-Active Duty Military Service

0.010

$-0.013$

$0.262 * *$

$-0.062$

(0.150)

$(0.127)$

(0.111)

(0.064)

$\widehat{\delta}_{\text {active duty }}-\widehat{\delta}_{\text {no active duty }}=0 ?[$ [p-value on F-test $]$

$0.115[0.49]$

0.151 [0.28]

$-0.103[0.41]$

$0.108[0.16]$

Observations

1,092

1,096

1,097

1,097

Robust standard errors are in parentheses. In Panel A, standard errors are corrected for clustering on the school level. $*, * *$, and $* * *$ indicate statistical significance at the $10 \%, 5 \%$, and $1 \%$ levels, respectively. All models in Panel A use the full set of controls shown in Appendix Table 1. Models in Panels B and C include controls for self-reported health status, height, weight, gender, marital status, age, income, education, health insurance status, and high school PPVT score. All models also include missing dummy categories for each of the control variables. 
Table 4: OLS Estimates of the Relationship between Deployment Assignment and Mental Health

\begin{tabular}{|c|c|c|c|c|}
\hline & Suicide & Depression & Counseling & PTSD \\
\hline Active Duty Military Service in Combat Zone & $\begin{array}{c}0.025^{*} \\
(0.014)\end{array}$ & $\begin{array}{c}0.037 * * \\
(0.018)\end{array}$ & $\begin{array}{c}0.096 * * * \\
(0.018)\end{array}$ & $\begin{array}{c}0.150 * * * \\
(0.016)\end{array}$ \\
\hline Active Duty Outside US in Non-Combat Zone & $\begin{array}{c}0.009 \\
(0.021)\end{array}$ & $\begin{array}{c}0.013 \\
(0.033)\end{array}$ & $\begin{array}{c}0.010 \\
(0.020)\end{array}$ & $\begin{array}{c}0.008 \\
(0.012)\end{array}$ \\
\hline Active Duty Military Service Exclusively in the US & $\begin{array}{c}0.023 \\
(0.016)\end{array}$ & $\begin{array}{c}0.026 \\
(0.020)\end{array}$ & $\begin{array}{c}0.017 \\
(0.016)\end{array}$ & $\begin{array}{c}0.021 * * \\
(0.010)\end{array}$ \\
\hline Non-Active Duty Military Service & $\begin{array}{c}0.011 \\
(0.021)\end{array}$ & $\begin{array}{c}0.002 \\
(0.029)\end{array}$ & $\begin{array}{c}0.035 \\
(0.022)\end{array}$ & $\begin{array}{c}0.042 * * \\
(0.018)\end{array}$ \\
\hline$\widehat{\delta}_{\text {combat }}-\widehat{\delta}_{\text {no active duty }}=0 ?$ [p-value on F-test $]$ & $0.014[0.60]$ & $0.035[0.34]$ & $0.061^{* *}[0.03]$ & $0.108^{* * *}[0.00]$ \\
\hline$\widehat{\delta}_{\text {combat }}-\widehat{\delta}_{\text {non-combat US }}=0 ?[\mathrm{p}$-value on F-test $]$ & $0.002[0.94]$ & $0.011[0.62]$ & $0.079^{* * *}[0.00]$ & $0.129^{* * *}[0.00]$ \\
\hline$\widehat{\delta}_{\text {combat }}-\widehat{\delta}_{\text {non-combat outside US }}=0 ?$ [p-value on F-test $]$ & $0.016[0.50]$ & $0.024[0.48]$ & $0.086^{* * *}[0.00]$ & $0.142^{* * *}[0.00]$ \\
\hline Observations & 15,593 & 15,689 & 15,695 & 15,696 \\
\hline
\end{tabular}

Robust standard errors corrected for clustering on the school are in parentheses. *,**, and *** indicate statistical significance at the $10 \%, 5 \%$, and $1 \%$ levels, respectively. All models use the full set of controls shown in Appendix Table 1 along with school fixed effects. Models also include missing dummy categories for each of the control variables. 
Table 5: Estimates of the Relationship between Deployment Assignment and Mental Health, Adjusting for Pre-Deployment Mental Health

\begin{tabular}{|c|c|c|c|c|}
\hline \multirow{2}{*}{\multicolumn{5}{|c|}{ Panel A: Controlling for Pre-Deployment Mental Health }} \\
\hline & & & & \\
\hline Active Duty Military Service in Combat Zone & $\begin{array}{l}0.024^{*} \\
(0.014)\end{array}$ & $\begin{array}{c}0.036 * * \\
(0.017)\end{array}$ & $\begin{array}{c}0.095 * * * \\
(0.019)\end{array}$ & $\begin{array}{c}0.154 * * * \\
(0.016)\end{array}$ \\
\hline Active Duty Outside US in Non-Combat Zone & $\begin{array}{c}0.012 \\
(0.021)\end{array}$ & $\begin{array}{c}0.021 \\
(0.034)\end{array}$ & $\begin{array}{c}0.014 \\
(0.020)\end{array}$ & $\begin{array}{c}0.009 \\
(0.012)\end{array}$ \\
\hline Active Duty Military Service Exclusively in the US & $\begin{array}{c}0.023 \\
(0.017)\end{array}$ & $\begin{array}{c}0.027 \\
(0.020)\end{array}$ & $\begin{array}{c}0.016 \\
(0.016)\end{array}$ & $\begin{array}{r}0.020^{* *} \\
(0.010)\end{array}$ \\
\hline Non-Active Duty Military Service & $\begin{array}{c}0.010 \\
(0.021)\end{array}$ & $\begin{array}{l}-0.008 \\
(0.029)\end{array}$ & $\begin{array}{c}0.034 \\
(0.023)\end{array}$ & $\begin{array}{l}0.044 * * \\
(0.019)\end{array}$ \\
\hline$\widehat{\delta}_{\text {combat }}-\widehat{\delta}_{\text {no active duty }}=0 ?[\mathrm{p}$-value on F-test $]$ & $0.014[0.58]$ & $0.044[0.21]$ & $0.061^{* *}[0.04]$ & $0.110^{* * *}[0.00]$ \\
\hline$\widehat{\delta}_{\text {combat }}-\widehat{\delta}_{\text {non-combat US }}=0 ?$ [p-value on F-test] & $0.001[0.97]$ & $0.009[0.66]$ & $0.079^{* * *}[0.00]$ & $0.134^{* * *}[0.00]$ \\
\hline$\widehat{\delta}_{\text {combat }}-\widehat{\delta}_{\text {non-combat outside US }}=0 ?[\mathrm{p}$-value on F-test $]$ & $0.012[0.62]$ & $0.015[0.65]$ & $0.081^{* * *}[0.00]$ & $0.145^{* * *}[0.00]$ \\
\hline Observations & 15,422 & 15,579 & 15,639 & 15,640 \\
\hline \multicolumn{5}{|l|}{ Panel B: Individual Fixed Effects } \\
\hline Active Duty Military Service in Combat Zone & $\begin{array}{l}0.031^{*} \\
(0.017)\end{array}$ & $\begin{array}{l}0.044 * \\
(0.024)\end{array}$ & $\begin{array}{c}0.087 * * * \\
(0.021)\end{array}$ & -- \\
\hline Active Duty Outside US in Non-Combat Zone & $\begin{array}{c}0.044 \\
(0.029)\end{array}$ & $\begin{array}{c}0.061 \\
(0.042)\end{array}$ & $\begin{array}{c}0.038 \\
(0.024)\end{array}$ & -- \\
\hline Active Duty Military Service Exclusively in the US & $\begin{array}{c}0.000 \\
(0.026)\end{array}$ & $\begin{array}{c}0.039 \\
(0.026)\end{array}$ & $\begin{array}{l}-0.007 \\
(0.023)\end{array}$ & -- \\
\hline Non-Active Duty Military Service & $\begin{array}{c}0.015 \\
(0.023)\end{array}$ & $\begin{array}{l}-0.000 \\
(0.033)\end{array}$ & $\begin{array}{c}0.000 \\
(0.031)\end{array}$ & -- \\
\hline$\widehat{\delta}_{\text {combat }}-\widehat{\delta}_{\text {no active duty }}=0 ?[\mathrm{p}$-value on F-test $]$ & $0.016[0.56]$ & $0.044[0.29]$ & $0.087^{* *}[0.02]$ & -- \\
\hline$\widehat{\delta}_{\text {combat }}-\widehat{\delta}_{\text {non-combat US }}=0 ?$ [p-value on F-test $]$ & $0.031[0.30]$ & $0.005[0.90]$ & $0.094^{* * *}[0.00]$ & -- \\
\hline$\widehat{\delta}_{\text {combat }}-\widehat{\delta}_{\text {non-combat outside US }}=0 ?$ [p-value on F-test $]$ & $-0.013[0.67]$ & $-0.017[0.70]$ & $0.049[0.14]$ & -- \\
\hline Observations & 15,422 & 15,579 & 15,639 & -- \\
\hline
\end{tabular}

Robust standard errors corrected for clustering on the school are in parentheses. ${ }^{*}, * *$, and $* * *$ indicate statistical significance at the $10 \%, 5 \%$, and $1 \%$ levels, respectively. Models in Panel A use the full set of controls shown in Appendix Table 1 along with school fixed effects and pre-deployment dependent variables. Models in Panel B control for the time varying individual characteristics: self reported health status indicators, height, weight, marital status indicators, age indicators, income, education indicators and an indicator of health insurance status. Models also include missing dummy categories for each of the control variables. 
Table 6: Estimates of the Relationship between Deployment Assignment and Mental Health for Military Population, Adjusting for Pre-Deployment Mental Health

\begin{tabular}{|c|c|c|c|c|}
\hline & Suicide & Depression & Counseling & PTSD \\
\hline \multicolumn{5}{|l|}{ Panel A: Military Sample } \\
\hline Active Duty Military Service in Combat Zone & $\begin{array}{c}0.039 \\
(0.032)\end{array}$ & $\begin{array}{c}0.061 \\
(0.044)\end{array}$ & $\begin{array}{c}0.088 * * \\
(0.037)\end{array}$ & $\begin{array}{c}0.136 * * * \\
(0.031)\end{array}$ \\
\hline Active Duty Outside US in Non-Combat Zone & $\begin{array}{c}0.030 \\
(0.038)\end{array}$ & $\begin{array}{c}0.012 \\
(0.054)\end{array}$ & $\begin{array}{c}0.015 \\
(0.042)\end{array}$ & $\begin{array}{c}0.015 \\
(0.029)\end{array}$ \\
\hline Active Duty Military Service Exclusively in the US & $\begin{array}{c}0.037 \\
(0.036)\end{array}$ & $\begin{array}{c}0.047 \\
(0.040)\end{array}$ & $\begin{array}{c}0.006 \\
(0.034)\end{array}$ & $\begin{array}{c}0.022 \\
(0.023)\end{array}$ \\
\hline $\begin{array}{l}\widehat{\delta}_{\text {combat }}-\widehat{\delta}_{\text {non-combat US }}=0 ?[\mathrm{p} \text {-value on F-test }] \\
\left.\widehat{\delta}_{\text {combat }}-\widehat{\delta}_{\text {non-combat outside US }}=0 ? \text { [p-value on F-test }\right]\end{array}$ & $\begin{array}{l}0.002[0.95] \\
0.009[0.74]\end{array}$ & $\begin{array}{l}0.014[0.64] \\
0.049[0.19]\end{array}$ & $\begin{array}{l}0.082^{* * *}[0.00] \\
0.073^{* *}[0.02]\end{array}$ & $\begin{array}{l}0.114^{* * *}[0.00] \\
0.121^{* * *}[0.00]\end{array}$ \\
\hline Observations & 1,069 & 1,077 & 1,077 & 1,078 \\
\hline \multicolumn{5}{|l|}{ Panel B: Army Sample } \\
\hline Active Duty Military Service in Combat Zone & $\begin{array}{c}0.049 \\
(0.057)\end{array}$ & $\begin{array}{c}0.035 \\
(0.085)\end{array}$ & $\begin{array}{c}0.149 * * * \\
(0.054)\end{array}$ & $\begin{array}{c}0.196 * * * \\
(0.067)\end{array}$ \\
\hline Active Duty Outside US in Non-Combat Zone & $\begin{array}{c}-0.034 \\
(0.077)\end{array}$ & $\begin{array}{l}-0.076 \\
(0.132)\end{array}$ & $\begin{array}{c}-0.004 \\
(0.075)\end{array}$ & $\begin{array}{c}0.006 \\
(0.071)\end{array}$ \\
\hline Active Duty Military Service Exclusively in the US & $\begin{array}{c}0.062 \\
(0.062)\end{array}$ & $\begin{array}{c}0.025 \\
(0.080)\end{array}$ & $\begin{array}{c}0.041 \\
(0.063)\end{array}$ & $\begin{array}{c}0.006 \\
(0.050)\end{array}$ \\
\hline $\begin{array}{l}\left.\widehat{\delta}_{\text {combat }}-\widehat{\delta}_{\text {non-combat US }}=0 ? \text { [p-value on F-test }\right] \\
\left.\widehat{\delta}_{\text {combat }}-\widehat{\delta}_{\text {non-combat outside US }}=0 ? \text { [p-value on F-test }\right]\end{array}$ & $\begin{array}{l}-0.013[0.83] \\
0.083[0.14]\end{array}$ & $\begin{array}{l}0.010[0.89] \\
0.060[0.23]\end{array}$ & $\begin{array}{l}0.108[0.14] \\
0.153^{*}[0.04]\end{array}$ & $\begin{array}{l}0.190^{* * *}[0.01] \\
0.190^{* * *}[0.01]\end{array}$ \\
\hline Observations & 480 & 481 & 482 & 482 \\
\hline \multicolumn{5}{|l|}{ Panel C: Army Post-9/11 Sample } \\
\hline Active Duty Military Service in Combat Zone & $\begin{array}{c}0.074 \\
(0.065)\end{array}$ & $\begin{array}{c}0.054 \\
(0.089)\end{array}$ & $\begin{array}{l}0.120^{*} \\
(0.067)\end{array}$ & $\begin{array}{c}0.167 * * \\
(0.081)\end{array}$ \\
\hline Active Duty Outside US in Non-Combat Zone & $\begin{array}{c}-0.003 \\
(0.077)\end{array}$ & $\begin{array}{c}-0.052 \\
(0.142)\end{array}$ & $\begin{array}{c}0.050 \\
(0.104)\end{array}$ & $\begin{array}{c}-0.013 \\
(0.091)\end{array}$ \\
\hline Active Duty Military Service Exclusively in the US & $\begin{array}{c}0.014 \\
(0.076)\end{array}$ & $\begin{array}{c}0.002 \\
(0.069)\end{array}$ & $\begin{array}{c}0.013 \\
(0.080)\end{array}$ & $\begin{array}{l}-0.024 \\
(0.074)\end{array}$ \\
\hline $\begin{array}{l}\widehat{\delta}_{\text {combat }}-\widehat{\delta}_{\text {non-combat US }}=0 ?[\mathrm{p} \text {-value on F-test }] \\
\widehat{\delta}_{\text {combat }}-\widehat{\delta}_{\text {non-combat outside US }}=0 ?[\mathrm{p} \text {-value on F-test }]\end{array}$ & $\begin{array}{c}0.060[0.33] \\
0.077[0.198]\end{array}$ & $\begin{array}{l}0.052[0.55] \\
0.106[0.35]\end{array}$ & $\begin{array}{l}0.107[0.15] \\
0.070[0.46]\end{array}$ & $\begin{array}{c}0.191^{* *}[0.02] \\
0.180^{*}[0.06]\end{array}$ \\
\hline Observations & 413 & 413 & 414 & 414 \\
\hline \multicolumn{5}{|l|}{ Panel D: Individual Fixed Effects, Army Sample } \\
\hline Active Duty Military Service in Combat Zone & $\begin{array}{c}0.027 \\
(0.052)\end{array}$ & $\begin{array}{l}-0.003 \\
(0.065)\end{array}$ & $\begin{array}{c}0.149 * * \\
(0.059)\end{array}$ & -- \\
\hline Active Duty Outside US in Non-Combat Zone & $\begin{array}{c}0.029 \\
(0.069)\end{array}$ & $\begin{array}{c}0.019 \\
(0.117)\end{array}$ & $\begin{array}{c}0.048 \\
(0.062)\end{array}$ & -- \\
\hline Active Duty Military Service Exclusively in the US & 0.032 & 0.050 & 0.044 & -- \\
\hline
\end{tabular}




\begin{tabular}{|c|c|c|c|c|}
\hline & $(0.063)$ & $(0.068)$ & $(0.057)$ & \\
\hline $\begin{array}{l}\widehat{\delta}_{\text {combat }}-\widehat{\delta}_{\text {non-combat US }}=0 ?[\mathrm{p} \text {-value on F-test }] \\
\widehat{\delta}_{\text {combat }}-\widehat{\delta}_{\text {non-combat outside US }}=0 ?[\mathrm{p} \text {-value on F-test }]\end{array}$ & $\begin{array}{l}-0.005[0.94] \\
-0.002[0.98]\end{array}$ & $\begin{array}{l}-0.053[0.39] \\
-0.022[0.82]\end{array}$ & $\begin{array}{c}0.105^{*}[0.09] \\
0.101[0.13]\end{array}$ & - \\
\hline Observations & 480 & 481 & 482 & - \\
\hline \multicolumn{5}{|c|}{ Panel E: Individual Fixed Effects, Army Post-9/11 Sample } \\
\hline Active Duty Military Service in Combat Zone & $\begin{array}{c}0.053 \\
(0.057)\end{array}$ & $\begin{array}{l}-0.011 \\
(0.067)\end{array}$ & $\begin{array}{l}0.120^{*} \\
(0.067)\end{array}$ & -- \\
\hline Active Duty Outside US in Non-Combat Zone & $\begin{array}{c}0.043 \\
(0.074)\end{array}$ & $\begin{array}{c}0.044 \\
(0.122)\end{array}$ & $\begin{array}{c}0.050 \\
(0.104)\end{array}$ & -- \\
\hline Active Duty Military Service Exclusively in the US & $\begin{array}{c}-0.002 \\
(0.069)\end{array}$ & $\begin{array}{l}-0.016 \\
(0.066)\end{array}$ & $\begin{array}{c}0.013 \\
(0.080)\end{array}$ & -- \\
\hline $\begin{array}{l}\widehat{\delta}_{\text {combat }}-\widehat{\delta}_{\text {non-combat US }}=0 ?[\mathrm{p} \text {-value on F-test }] \\
\widehat{\delta}_{\text {combat }}-\widehat{\delta}_{\text {non-combat outside US }}=0 ?[\mathrm{p} \text {-value on F-test }]\end{array}$ & $\begin{array}{l}0.055[0.40] \\
0.010[0.89]\end{array}$ & $\begin{array}{c}0.005[0.94] \\
-0.055[0.60]\end{array}$ & $\begin{array}{l}0.107^{* *}[0.02] \\
0.070^{* *}[0.04]\end{array}$ & - \\
\hline Observations & 413 & 413 & 414 & - \\
\hline $\begin{array}{l}\text { Robust standard errors corrected for clustering on } \\
\text { significance at the } 10 \%, 5 \% \text {, and } 1 \% \text { levels, respe } \\
\text { shown in Appendix Table } 1 \text { along with school fix } \\
\text { branch of service, occupation indicators, and an in } \\
\text { D and E also control for all the time varying chara } \\
\text { status indicators, height, weight, marital status ind } \\
\text { of health insurance status, military rank, timing of } \\
\text { indicator for having a check-up in the past year. } \\
\text { control variables. }\end{array}$ & $\begin{array}{l}\text { school are in pe } \\
\text { vely. Models in } \\
\text { effects as well as } \\
\text { cator for having } \\
\text { eristics controllec } \\
\text { tors, age indicat } \\
\text { ilitary service, bi } \\
\text { lels also include }\end{array}$ & $\begin{array}{l}\text { rentheses. *, **, } \\
\text { anels A, B, and } \\
\text { military rank, tir } \\
\text { check-up in the } \\
\text { in Panels A, B, a } \\
\text { rs, income, educ } \\
\text { anch of service, o } \\
\text { nissing dummy c }\end{array}$ & $\begin{array}{l}\text { nd** indicate st } \\
\text { use the full set of } \\
\text { ing of military se } \\
\text { ast year. Models } \\
\text { d C: self reported } \\
\text { ion indicators, an } \\
\text { cupation indicato } \\
\text { tegories for each }\end{array}$ & \\
\hline
\end{tabular}

\section{Table 7: Estimated Effect of Combat Zone Deployment Length on Mental Health for those who Deployed} to Combat Zone

\begin{tabular}{|c|c|c|c|c|}
\hline & Suicide & Depression & Counseling & PTSD \\
\hline Combat Zone Service Length: 7 to 12 Months & $\begin{array}{c}0.017 \\
(0.049)\end{array}$ & $\begin{array}{c}0.034 \\
(0.072)\end{array}$ & $\begin{array}{c}0.025 \\
(0.062)\end{array}$ & $\begin{array}{l}-0.014 \\
(0.057)\end{array}$ \\
\hline Combat Zone Service Length: More than 12 Months & $\begin{array}{l}-0.000 \\
(0.057)\end{array}$ & $\begin{array}{c}0.033 \\
(0.078)\end{array}$ & $\begin{array}{c}0.098 \\
(0.073)\end{array}$ & $\begin{array}{l}0.129^{*} \\
(0.074)\end{array}$ \\
\hline$\widehat{\delta}_{\text {more than } 12 \text { months }}-\widehat{\delta}_{7 \text { to } 12 \text { months }}=0 ?$ [p-value on F-test $]$ & $-0.017[0.74]$ & $-0.001[0.99]$ & $0.073[0.32]$ & $0.143^{* *}[0.041]$ \\
\hline Observations & 425 & 427 & 427 & 427 \\
\hline
\end{tabular}

Robust standard errors corrected for clustering on the school are in parentheses. ${ }^{*},{ }^{*}$, and $* * *$ indicate statistical significance at the $10 \%, 5 \%$, and $1 \%$ levels, respectively. All models use the time varying set of controls shown in Appendix Table 1 along with school fixed effects as well as additional controls for pre-deployment mental health, military rank, timing of military service, branch of service, occupation indicators, and an indicator for having a check-up in the past year. Models also include missing dummy categories for each of the control variables. 
Table 8: Estimated Effect of Frequency of Enemy Firefight Engagement on Mental Health of those who Deployed to Combat Zone

\begin{tabular}{lcccc}
\hline & Suicide & Depression & Counseling & PTSD \\
\hline Panel A: Any Enemy Firefights & & & & \\
& & & & \\
Any Enemy Firefights & $0.104^{* * *}$ & 0.091 & $0.112^{* *}$ & $0.183^{* * *}$ \\
& $(0.038)$ & $(0.063)$ & $(0.049)$ & $(0.053)$ \\
Observations & 412 & 414 & 414 & 414
\end{tabular}

\section{Panel B: Categorical Enemy Firefights}

1 to 3 Enemy Firefights

$\begin{array}{cccc}0.069 & 0.042 & 0.101 & 0.078 \\ (0.049) & (0.091) & (0.092) & (0.082) \\ 0.057 & 0.125 & 0.058 & 0.153^{*} \\ (0.064) & (0.102) & (0.071) & (0.087) \\ 0.183^{* *} & 0.120 & 0.172 * * & 0.331 * * * \\ (0.076) & (0.080) & (0.078) & (0.089)\end{array}$

$\widehat{\delta}_{20 \text { or More Firefight }}-\widehat{\delta}_{1 \text { to } 3 \text { Firefight }}=0$ ? [p-value on F-test]

$\begin{array}{lccc}0.114[0.20] & 0.078[0.47] & 0.071[0.59] & 0.253^{* *}[0.02] \\ 0.126[0.23] & -0.005[0.96] & 0.114[0.30] & 0.178[0.16]\end{array}$

$\widehat{\delta}_{20 \text { or More Firefight }}-\widehat{\delta}_{4 \text { to } 19 \text { Firefight }}=0$ ? [p-value on F-test]

414

414

\section{Panel C: Conditional on Combat Deployment Length}

1 to 3 Enemy Firefights

4 to 19 Enemy Firefights

20 or More Enemy Firefights

Combat Zone Service Length: 7 to 12 Months (\%)

Combat Zone Service Length: More than 12 Months (\%)

$\widehat{\delta}_{20 \text { or More Firefight }}-\widehat{\delta}_{1 \text { to } 3 \text { Firefight }}=0$ ? [p-value on F-test $]$

$\widehat{\delta}_{20 \text { or More Firefight }}-\widehat{\delta}_{4}$ to 19 Firefight $=0 ?$ [p-value on F-test]

$\begin{array}{cccc}0.073 & 0.043 & 0.099 & 0.075 \\ (0.049) & (0.091) & (0.092) & (0.081) \\ 0.070 & 0.125 & 0.048 & 0.148^{*} \\ (0.067) & (0.106) & (0.071) & (0.085) \\ 0.209^{* * *} & 0.123 & 0.151^{*} & 0.306^{* * *} \\ (0.079) & (0.093) & (0.088) & (0.095) \\ -0.009 & 0.010 & 0.007 & -0.044 \\ (0.054) & (0.077) & (0.062) & (0.056) \\ -0.069 & -0.004 & 0.056 & 0.041 \\ (0.057) & (0.091) & (0.080) & (0.076)\end{array}$

$\begin{array}{cccc}0.136[0.13] & 0.08[0.50] & 0.052[0.71] & 0.231^{* *}[0.03] \\ 0.139[0.20] & -0.002[0.99] & 0.103[0.36] & 0.158[0.21]\end{array}$

412

414

414

Robust standard errors corrected for clustering on the school are in parentheses. $*, * *$, and $* * *$ indicate statistical significance at the $10 \%, 5 \%$, and $1 \%$ levels, respectively. All models use the time varying set of controls shown in Appendix Table 1 along with school fixed effects as well as additional controls for pre-deployment mental health, military rank, timing of military service, branch of service, occupation indicators, and an indicator for having a check-up in the past year. Models also include missing dummy categories for each of the control variables. 
Table 9: Estimated Effect of Battlefield Deaths or Injuries on Mental Health of those who Deployed to Combat Zone, Conditional on Deployment Length

\begin{tabular}{lcccc}
\hline & Suicide & Depression & Counseling & PTSD \\
\hline Panel A: Killed or Believed Killed Another & & & & \\
& & & & \\
Killed or Believed Killed Another & $0.120^{* * *}$ & $0.130 * *$ & 0.032 & $0.222^{* * *}$ \\
& $(0.042)$ & $(0.061)$ & $(0.053)$ & $(0.059)$ \\
Combat Zone Service Length: 7 to 12 Months & 0.014 & 0.069 & 0.038 & -0.020 \\
& $(0.051)$ & $(0.073)$ & $(0.061)$ & $(0.061)$ \\
Combat Zone Service Length: More than 12 Months & -0.045 & 0.050 & $0.132^{*}$ & 0.070 \\
& $(0.058)$ & $(0.076)$ & $(0.076)$ & $(0.069)$
\end{tabular}

Observations

414

416

417

417

\section{Panel B: Injury}

Wounded or Injured in Combat

$\begin{array}{cccc}0.105 & 0.184 * & 0.275^{* *} & 0.239 * * \\ (0.084) & (0.107) & (0.106) & (0.107) \\ 0.021 & 0.062 & 0.052 & -0.015 \\ (0.047) & (0.073) & (0.063) & (0.056) \\ -0.018 & 0.053 & 0.122^{*} & 0.103 \\ (0.052) & (0.066) & (0.069) & (0.066)\end{array}$

Combat Zone Service Length: 7 to 12 Months

424

Observations

Panel C: Observe Death or Wounding

Saw Coalition or Ally Killed, Dead, or Wounded

$\begin{array}{cccc}0.094 * * & 0.087 & 0.022 & 0.082 \\ (0.040) & (0.053) & (0.062) & (0.066) \\ 0.101 * & 0.024 & 0.090 & 0.157 * * \\ (0.060) & (0.083) & (0.066) & (0.076) \\ -0.028 & 0.018 & 0.014 & 0.022 \\ (0.064) & (0.081) & (0.069) & (0.081) \\ 0.017 & 0.051 & 0.043 & -0.017 \\ (0.044) & (0.074) & (0.057) & (0.056) \\ -0.057 & 0.031 & 0.111 & 0.062 \\ (0.054) & (0.072) & (0.073) & (0.065)\end{array}$

$\widehat{\delta}_{\text {coalition }}-\widehat{\delta}_{\text {enemy }}=0 ?$ [p-value on F-test $]$

$0.122[0.11]$

$0.069[0.50]$

$0.008[0.93]$

$0.060[0.62]$

$\widehat{\delta}_{\text {civilian }}-\widehat{\delta}_{\text {enemy }}=0 ?$ [p-value on F-test]

$0.129[0.26] \quad 0.006[0.97] \quad 0.076[0.52]$

$0.135[0.34]$

Observations

422

424

424

424

Robust standard errors corrected for clustering on the school are in parentheses. *, **, and *** indicate statistical significance at the $10 \%, 5 \%$, and $1 \%$ levels, respectively. All models use the set of controls shown in Appendix Table 1 along with school fixed effects as well as additional controls for pre-deployment mental health, military rank, timing of military service, branch of service, occupation indicators, and an indicator for having a check-up in the past year. Models also include missing dummy categories for each of the control variables. 
Table 10: Estimated Effect of Battlefield Deaths or Injuries on Mental Health of those who Deployed to Combat Zone, Conditional on Deployment Length and Frequency of Enemy Firefight Engagement

Panel A: Killed or Believed Killed Another

Suicide

Killed or Believed Killed Another

1 to 3 Enemy Firefights

4 to 19 Enemy Firefights

20 or More Enemy Firefights

Combat Zone Service Length: 7 to 12 Months (\%)

Combat Zone Service Length: More than 12 Months (\%)
Depression

$\begin{array}{cccc}0.042 & -0.050 & -0.079 & 0.137 \\ (0.074) & (0.104) & (0.110) & (0.120) \\ 0.053 & 0.074 & 0.123 & 0.025 \\ (0.063) & (0.105) & (0.116) & (0.088) \\ 0.05 & 0.226 & 0.094 & 0.069 \\ (0.085) & (0.139) & (0.132) & (0.127) \\ 0.178^{*} & 0.161 & 0.215^{*} & 0.181 \\ (0.102) & (0.129) & (0.128) & (0.145) \\ -0.01 & 0.023 & 0.016 & -0.029 \\ (0.059) & (0.080) & (0.067) & (0.061) \\ -0.076 & -0.009 & 0.075 & 0.051 \\ (0.059) & (0.091) & (0.083) & (0.077)\end{array}$

404

Panel B: Injury

Wounded or Injured in Combat

1 to 3 Enemy Firefights

4 to 19 Enemy Firefights

20 or More Enemy Firefights

Combat Zone Service Length: 7 to 12 Months (\%)

Combat Zone Service Length: More than 12 Months (\%)

Observations

Panel C: Observe Death or Wounding on Battlefield

Saw Coalition or Ally Killed, Dead, or Wounded

Saw Civilian Killed, Dead, or Wounded

Saw Enemy Killed, Dead, or Wounded

1 to 3 Enemy Firefights

4 to 19 Enemy Firefights

20 or More Enemy Firefights

$\begin{array}{cccc}0.029 & 0.154 & 0.250^{* *} & 0.117 \\ (0.089) & (0.121) & (0.098) & (0.099) \\ 0.072 & 0.036 & 0.088 & 0.07 \\ (0.049) & (0.088) & (0.088) & (0.081) \\ 0.067 & 0.108 & 0.019 & 0.135 \\ (0.067) & (0.107) & (0.068) & (0.087) \\ 0.204 * * * & 0.096 & 0.106 & 0.286^{* * *} \\ (0.077) & (0.092) & (0.089) & (0.095) \\ -0.006 & 0.024 & 0.03 & -0.033 \\ (0.054) & (0.080) & (0.066) & (0.057) \\ -0.069 & 0.001 & 0.064 & 0.045 \\ (0.058) & (0.094) & (0.087) & (0.077)\end{array}$

412

414

414

414

$\begin{array}{cccc}0.072 & 0.066 & 0.006 & 0.010 \\ (0.048) & (0.065) & (0.084) & (0.064) \\ 0.105 & 0.054 & 0.104 & 0.148^{*} \\ (0.077) & (0.097) & (0.084) & (0.082) \\ -0.049 & -0.041 & -0.023 & -0.014 \\ (0.070) & (0.083) & (0.074) & (0.096) \\ 0.053 & 0.028 & 0.096 & 0.054 \\ (0.053) & (0.093) & (0.105) & (0.082) \\ 0.025 & 0.11 & 0.017 & 0.112 \\ (0.066) & (0.126) & (0.106) & (0.098) \\ 0.157^{*} & 0.093 & 0.113 & 0.245^{* *} \\ (0.083) & (0.114) & (0.108) & (0.106)\end{array}$


Combat Zone Service Length: 7 to 12 Months (\%)

Combat Zone Service Length: More than 12 Months (\%)

$\widehat{\delta}_{\text {coalition }}-\widehat{\delta}_{\text {enemy }}=0 ?$ [p-value on F-test $]$

$\widehat{\delta}_{\text {civilian }}-\widehat{\delta}_{\text {enemy }}=0 ?$ [p-value on F-test $]$

$\begin{array}{cccc}-0.004 & 0.008 & 0.014 & -0.034 \\ (0.050) & (0.082) & (0.060) & (0.058) \\ -0.086 & -0.016 & 0.051 & 0.039 \\ (0.055) & (0.092) & (0.080) & (0.077) \\ & & & \\ 0.121[0.14] & 0.107[0.33] & 0.029[0.78] & 0.024[0.84] \\ 0.154[0.26] & 0.095[0.53] & 0.127[0.30] & 0.162[0.30]\end{array}$

410

412

412

412

Robust standard errors corrected for clustering on the school are in parentheses. *, **, and *** indicate statistical significance at the $10 \%, 5 \%$, and $1 \%$ levels, respectively. All models use the time varying set of controls shown in Appendix Table 1 along with school fixed effects as well as additional controls for pre-deployment mental health, military rank, timing of military service, and branch of service, branch of service, occupation indicators, and an indicator for having a check-up in the past year. Models also include missing dummy categories for each of the control variables. 
Appendix Table 1: Summary Statistics by Military Service

\begin{tabular}{|c|c|c|c|c|c|c|c|c|}
\hline Variable & $\begin{array}{c}\text { Full } \\
\text { Sample }\end{array}$ & Civilian & $\begin{array}{c}\text { Any } \\
\text { Military } \\
\text { Service }\end{array}$ & $\begin{array}{l}\text { Non-Active } \\
\text { Duty } \\
\text { Service }\end{array}$ & $\begin{array}{l}\text { Active Duty } \\
\text { Inside US } \\
\text { (no combat) }\end{array}$ & $\begin{array}{l}\text { Active Duty } \\
\text { Outside US } \\
\text { Non-Combat }\end{array}$ & $\begin{array}{c}\text { Active Duty } \\
\text { in Combat } \\
\text { Zone }\end{array}$ & $\begin{array}{c}\text { Combat } \\
\text { with } \geq 1 \\
\text { Enemy } \\
\text { Firefights } \\
\end{array}$ \\
\hline Race: White, omitted & $\begin{array}{c}0.697 \\
(0.460)\end{array}$ & $\begin{array}{c}0.699 \\
(0.459)\end{array}$ & $\begin{array}{c}0.672 \\
(0.470)\end{array}$ & $\begin{array}{c}0.663 \\
(0.474)\end{array}$ & $\begin{array}{c}0.697 \\
(0.460)\end{array}$ & $\begin{array}{c}0.667 \\
(0.473)\end{array}$ & $\begin{array}{c}0.658 \\
(0.475)\end{array}$ & $\begin{array}{c}0.717 \\
(0.452)\end{array}$ \\
\hline Race: Black & $\begin{array}{c}0.231 \\
(0.421)\end{array}$ & $\begin{array}{c}0.229 \\
(0.420)\end{array}$ & $\begin{array}{c}0.256 \\
(0.437)\end{array}$ & $\begin{array}{c}0.291 \\
(0.456)\end{array}$ & $\begin{array}{c}0.236 \\
(0.425)\end{array}$ & $\begin{array}{c}0.275 \\
(0.448)\end{array}$ & $\begin{array}{c}0.251 \\
(0.434)\end{array}$ & $\begin{array}{c}0.215 \\
(0.412)\end{array}$ \\
\hline Race: Other & $\begin{array}{c}0.071 \\
(0.256)\end{array}$ & $\begin{array}{c}0.071 \\
(0.256)\end{array}$ & $\begin{array}{c}0.070 \\
(0.256)\end{array}$ & $\begin{array}{c}0.040 \\
(0.197)\end{array}$ & $\begin{array}{c}0.067 \\
(0.251)\end{array}$ & $\begin{array}{c}0.059 \\
(0.236)\end{array}$ & $\begin{array}{c}0.089 \\
(0.285)\end{array}$ & $\begin{array}{c}0.063 \\
(0.243)\end{array}$ \\
\hline Race: Hispanic & $\begin{array}{c}0.159 \\
(0.366)\end{array}$ & $\begin{array}{c}0.160 \\
(0.367)\end{array}$ & $\begin{array}{c}0.145 \\
(0.352)\end{array}$ & $\begin{array}{c}0.120 \\
(0.326)\end{array}$ & $\begin{array}{c}0.143 \\
(0.350)\end{array}$ & $\begin{array}{c}0.157 \\
(0.365)\end{array}$ & $\begin{array}{c}0.153 \\
(0.360)\end{array}$ & $\begin{array}{c}0.115 \\
(0.320)\end{array}$ \\
\hline Missing Data: Race & $\begin{array}{c}0.002 \\
(0.042)\end{array}$ & $\begin{array}{c}0.002 \\
(0.042)\end{array}$ & $\begin{array}{c}0.002 \\
(0.042)\end{array}$ & $\begin{array}{c}0.006 \\
(0.076)\end{array}$ & $\begin{array}{l}0.000 \\
0.000\end{array}$ & $\begin{array}{l}0.000 \\
0.000\end{array}$ & $\begin{array}{c}0.002 \\
(0.048)\end{array}$ & $\begin{array}{c}0.005 \\
(0.072)\end{array}$ \\
\hline Missing Data: Race - Hispanic & $\begin{array}{c}0.003 \\
(0.054)\end{array}$ & $\begin{array}{c}0.003 \\
(0.055)\end{array}$ & $\begin{array}{c}0.002 \\
(0.042)\end{array}$ & $\begin{array}{c}0.006 \\
(0.076)\end{array}$ & $\begin{array}{l}0.000 \\
0.000\end{array}$ & $\begin{array}{l}0.000 \\
0.000\end{array}$ & $\begin{array}{c}0.002 \\
(0.048)\end{array}$ & $\begin{array}{l}0.000 \\
0.000\end{array}$ \\
\hline Male & $\begin{array}{c}0.468 \\
(0.499)\end{array}$ & $\begin{array}{c}0.443 \\
(0.497)\end{array}$ & $\begin{array}{c}0.792 \\
(0.406)\end{array}$ & $\begin{array}{c}0.726 \\
(0.447)\end{array}$ & $\begin{array}{c}0.714 \\
(0.452)\end{array}$ & $\begin{array}{c}0.797 \\
(0.403)\end{array}$ & $\begin{array}{c}0.877 \\
(0.329)\end{array}$ & $\begin{array}{c}0.953 \\
(0.213)\end{array}$ \\
\hline Height in Inches & $\begin{array}{l}67.314 \\
(4.140)\end{array}$ & $\begin{array}{l}67.174 \\
(4.134)\end{array}$ & $\begin{array}{l}69.142 \\
(3.771)\end{array}$ & $\begin{array}{l}68.749 \\
(3.854)\end{array}$ & $\begin{array}{l}68.735 \\
(3.737)\end{array}$ & $\begin{array}{l}69.144 \\
(3.829)\end{array}$ & $\begin{array}{l}69.617 \\
(3.701)\end{array}$ & $\begin{array}{l}70.178 \\
(3.550)\end{array}$ \\
\hline Missing Data: Height in Inches & $\begin{array}{c}0.002 \\
(0.047)\end{array}$ & $\begin{array}{c}0.002 \\
(0.048)\end{array}$ & $\begin{array}{l}0.000 \\
0.000\end{array}$ & $\begin{array}{l}0.000 \\
0.000\end{array}$ & $\begin{array}{l}0.000 \\
0.000\end{array}$ & $\begin{array}{l}0.000 \\
0.000\end{array}$ & $\begin{array}{l}0.000 \\
0.000\end{array}$ & $\begin{array}{l}0.000 \\
0.000\end{array}$ \\
\hline Weight in Pounds & $\begin{array}{l}183.314 \\
(49.329)\end{array}$ & $\begin{array}{l}182.915 \\
(50.083)\end{array}$ & $\begin{array}{l}188.498 \\
(37.835)\end{array}$ & $\begin{array}{l}188.949 \\
(39.410)\end{array}$ & $\begin{array}{l}187.450 \\
(40.953)\end{array}$ & $\begin{array}{l}190.388 \\
(38.818)\end{array}$ & $\begin{array}{l}188.481 \\
(34.239)\end{array}$ & $\begin{array}{l}190.232 \\
(31.973)\end{array}$ \\
\hline Missing Data: Weight in Pounds & $\begin{array}{c}0.014 \\
(0.117)\end{array}$ & $\begin{array}{c}0.015 \\
(0.120)\end{array}$ & $\begin{array}{c}0.004 \\
(0.060)\end{array}$ & $\begin{array}{l}0.000 \\
0.000\end{array}$ & $\begin{array}{c}0.003 \\
(0.054)\end{array}$ & $\begin{array}{c}0.007 \\
(0.081)\end{array}$ & $\begin{array}{c}0.005 \\
(0.067)\end{array}$ & $\begin{array}{c}0.005 \\
(0.072)\end{array}$ \\
\hline Education: Less than High School, Omitted & $\begin{array}{c}0.080 \\
(0.271)\end{array}$ & $\begin{array}{c}0.085 \\
(0.279)\end{array}$ & $\begin{array}{c}0.011 \\
(0.104)\end{array}$ & $\begin{array}{c}0.023 \\
(0.150)\end{array}$ & $\begin{array}{c}0.012 \\
(0.108)\end{array}$ & $\begin{array}{c}0.020 \\
(0.139)\end{array}$ & $\begin{array}{c}0.002 \\
(0.048)\end{array}$ & $\begin{array}{c}0.005 \\
(0.072)\end{array}$ \\
\hline Education: High School & $\begin{array}{c}0.163 \\
(0.370)\end{array}$ & $\begin{array}{c}0.164 \\
(0.370)\end{array}$ & $\begin{array}{c}0.159 \\
(0.365)\end{array}$ & $\begin{array}{c}0.126 \\
(0.333)\end{array}$ & $\begin{array}{c}0.192 \\
(0.395)\end{array}$ & $\begin{array}{c}0.150 \\
(0.359)\end{array}$ & $\begin{array}{c}0.148 \\
(0.356)\end{array}$ & $\begin{array}{c}0.162 \\
(0.370)\end{array}$ \\
\hline Education: Some College or Vocational Training & $\begin{array}{c}0.441 \\
(0.497)\end{array}$ & $\begin{array}{c}0.425 \\
(0.494)\end{array}$ & $\begin{array}{c}0.653 \\
(0.476)\end{array}$ & $\begin{array}{c}0.629 \\
(0.485)\end{array}$ & $\begin{array}{c}0.633 \\
(0.483)\end{array}$ & $\begin{array}{c}0.680 \\
(0.468)\end{array}$ & $\begin{array}{c}0.670 \\
(0.471)\end{array}$ & $\begin{array}{c}0.675 \\
(0.470)\end{array}$ \\
\hline Education: College Degree & $\begin{array}{c}0.238 \\
(0.426)\end{array}$ & $\begin{array}{c}0.245 \\
(0.430)\end{array}$ & $\begin{array}{c}0.147 \\
(0.354)\end{array}$ & $\begin{array}{c}0.154 \\
(0.362)\end{array}$ & $\begin{array}{c}0.137 \\
(0.344)\end{array}$ & $\begin{array}{c}0.111 \\
(0.315)\end{array}$ & $\begin{array}{c}0.164 \\
(0.371)\end{array}$ & $\begin{array}{c}0.136 \\
(0.344)\end{array}$ \\
\hline Education: Graduate or Professional Degree & $\begin{array}{c}0.078 \\
(0.268)\end{array}$ & $\begin{array}{c}0.081 \\
(0.273)\end{array}$ & $\begin{array}{c}0.031 \\
(0.172)\end{array}$ & $\begin{array}{c}0.069 \\
(0.253)\end{array}$ & $\begin{array}{c}0.026 \\
(0.160)\end{array}$ & $\begin{array}{c}0.039 \\
(0.195)\end{array}$ & $\begin{array}{c}0.016 \\
(0.125)\end{array}$ & $\begin{array}{c}0.021 \\
(0.144)\end{array}$ \\
\hline Missing Data: Education & $\begin{array}{c}0.000 \\
(0.016)\end{array}$ & $\begin{array}{c}0.000 \\
(0.017)\end{array}$ & $\begin{array}{l}0.000 \\
0.000\end{array}$ & $\begin{array}{l}0.000 \\
0.000\end{array}$ & $\begin{array}{l}0.000 \\
0.000\end{array}$ & $\begin{array}{l}0.000 \\
0.000\end{array}$ & $\begin{array}{l}0.000 \\
0.000\end{array}$ & $\begin{array}{l}0.000 \\
0.000\end{array}$ \\
\hline Personal Earnings & $\begin{array}{c}35215.910 \\
(45020.320)\end{array}$ & $\begin{array}{c}34859.690 \\
(45524.200)\end{array}$ & $\begin{array}{c}39794.850 \\
(37671.330)\end{array}$ & $\begin{array}{c}35057.910 \\
(24703.470)\end{array}$ & $\begin{array}{c}36605.010 \\
(31696.050)\end{array}$ & $\begin{array}{c}37840.030 \\
(24342.040)\end{array}$ & $\begin{array}{c}44783.870 \\
(47999.020)\end{array}$ & $\begin{array}{c}43576.800 \\
(24319.940)\end{array}$ \\
\hline Missing Data: Personal Earnings & $\begin{array}{c}0.050 \\
(0.217)\end{array}$ & $\begin{array}{c}0.051 \\
(0.220)\end{array}$ & $\begin{array}{c}0.030 \\
(0.170)\end{array}$ & $\begin{array}{c}0.029 \\
(0.167)\end{array}$ & $\begin{array}{c}0.038 \\
(0.191)\end{array}$ & $\begin{array}{c}0.039 \\
(0.195)\end{array}$ & $\begin{array}{c}0.021 \\
(0.142)\end{array}$ & $\begin{array}{c}0.011 \\
(0.102)\end{array}$ \\
\hline General Physical Health is Excellent & 0.192 & 0.189 & 0.234 & 0.211 & 0.207 & 0.255 & 0.257 & 0.257 \\
\hline
\end{tabular}


General Physical Health is Fair or Poor

$=1$ if 24 years old, $=0$ otherwise

$=1$ if 25 years old, $=0$ otherwise

$=1$ if 26 years old, $=0$ otherwise

$=1$ if 27 years old, $=0$ otherwise

$=1$ if 28 years old, $=0$ otherwise

$=1$ if 29 years old, $=0$ otherwise, omitted

$=1$ if 30 years old, $=0$ otherwise

$=1$ if 31 years old, $=0$ otherwise

$=1$ if 32 years old, $=0$ otherwise

$=1$ if 33 years old, $=0$ otherwise

$=1$ if 34 years old, $=0$ otherwise

Religion: None, Atheist, or Agnostic, Omitted

Religion: Protestant

Religion: Catholic

Religion: Other Christian

Religion: Other

Missing Data: Religion

Never Married

Currently Married

Divorced

No Health Insurance

\begin{tabular}{|c|c|c|c|c|c|c|c|}
\hline (0.394) & $(0.391)$ & $(0.424)$ & $(0.410)$ & $(0.406)$ & $(0.437)$ & $(0.438)$ & $(0.438)$ \\
\hline 0.097 & 0.099 & 0.065 & 0.063 & 0.079 & 0.059 & 0.057 & 0.047 \\
\hline$(0.296)$ & $(0.299)$ & $(0.246)$ & $(0.243)$ & $(0.270)$ & $(0.236)$ & $(0.232)$ & $(0.213)$ \\
\hline 0.002 & 0.002 & 0.000 & 0.000 & 0.000 & 0.000 & 0.000 & 0.000 \\
\hline$(0.045)$ & $(0.047)$ & 0.000 & 0.000 & 0.000 & 0.000 & 0.000 & 0.000 \\
\hline 0.044 & 0.045 & 0.038 & 0.051 & 0.032 & 0.033 & 0.039 & 0.063 \\
\hline$(0.205)$ & $(0.207)$ & $(0.191)$ & $(0.222)$ & $(0.176)$ & $(0.178)$ & $(0.193)$ & $(0.243)$ \\
\hline 0.116 & 0.117 & 0.103 & 0.103 & 0.120 & 0.046 & 0.109 & 0.079 \\
\hline$(0.320)$ & $(0.321)$ & $(0.304)$ & $(0.305)$ & $(0.325)$ & $(0.210)$ & $(0.312)$ & $(0.270)$ \\
\hline 0.145 & 0.146 & 0.127 & 0.137 & 0.140 & 0.098 & 0.123 & 0.120 \\
\hline$(0.352)$ & $(0.353)$ & $(0.333)$ & $(0.345)$ & $(0.347)$ & $(0.298)$ & $(0.329)$ & $(0.326)$ \\
\hline 0.180 & 0.179 & 0.192 & 0.211 & 0.190 & 0.183 & 0.189 & 0.199 \\
\hline$(0.384)$ & $(0.384)$ & $(0.394)$ & $(0.410)$ & $(0.393)$ & $(0.388)$ & $(0.392)$ & $(0.400)$ \\
\hline 0.189 & 0.188 & 0.198 & 0.149 & 0.204 & 0.229 & 0.203 & 0.204 \\
\hline$(0.392)$ & $(0.391)$ & $(0.399)$ & $(0.357)$ & $(0.404)$ & $(0.421)$ & $(0.403)$ & $(0.404)$ \\
\hline 0.183 & 0.184 & 0.178 & 0.206 & 0.160 & 0.183 & 0.178 & 0.168 \\
\hline$(0.387)$ & $(0.387)$ & $(0.382)$ & $(0.405)$ & $(0.368)$ & $(0.388)$ & $(0.383)$ & $(0.374)$ \\
\hline 0.116 & 0.114 & 0.142 & 0.114 & 0.131 & 0.216 & 0.137 & 0.136 \\
\hline$(0.320)$ & $(0.318)$ & $(0.350)$ & $(0.319)$ & $(0.338)$ & $(0.413)$ & $(0.344)$ & $(0.344)$ \\
\hline 0.021 & 0.021 & 0.022 & 0.029 & 0.023 & 0.013 & 0.021 & 0.026 \\
\hline$(0.144)$ & $(0.144)$ & $(0.146)$ & $(0.167)$ & $(0.151)$ & $(0.114)$ & $(0.142)$ & $(0.160)$ \\
\hline 0.003 & 0.003 & 0.001 & 0.000 & 0.000 & 0.000 & 0.002 & 0.005 \\
\hline$(0.055)$ & $(0.056)$ & $(0.030)$ & 0.000 & 0.000 & 0.000 & $(0.048)$ & $(0.072)$ \\
\hline 0.000 & 0.000 & 0.000 & 0.000 & 0.000 & 0.000 & 0.000 & 0.000 \\
\hline$(0.018)$ & $(0.019)$ & 0.000 & 0.000 & 0.000 & 0.000 & 0.000 & 0.000 \\
\hline 0.181 & 0.181 & 0.187 & 0.166 & 0.187 & 0.211 & 0.188 & 0.194 \\
\hline$(0.385)$ & $(0.385)$ & $(0.390)$ & $(0.373)$ & $(0.390)$ & $(0.409)$ & $(0.391)$ & $(0.396)$ \\
\hline 0.292 & 0.289 & 0.332 & 0.411 & 0.306 & 0.270 & 0.341 & 0.382 \\
\hline$(0.455)$ & $(0.453)$ & $(0.471)$ & $(0.494)$ & $(0.462)$ & $(0.445)$ & $(0.475)$ & $(0.487)$ \\
\hline 0.219 & 0.220 & 0.208 & 0.177 & 0.201 & 0.204 & 0.227 & 0.220 \\
\hline$(0.414)$ & $(0.414)$ & $(0.406)$ & $(0.383)$ & $(0.402)$ & $(0.404)$ & $(0.419)$ & $(0.415)$ \\
\hline 0.224 & 0.226 & 0.207 & 0.206 & 0.230 & 0.197 & 0.192 & 0.157 \\
\hline$(0.417)$ & $(0.418)$ & $(0.405)$ & $(0.405)$ & $(0.422)$ & $(0.399)$ & $(0.395)$ & $(0.365)$ \\
\hline 0.083 & 0.085 & 0.067 & 0.040 & 0.076 & 0.118 & 0.053 & 0.047 \\
\hline$(0.277)$ & $(0.278)$ & $(0.250)$ & $(0.197)$ & $(0.265)$ & $(0.324)$ & $(0.224)$ & $(0.213)$ \\
\hline 0.003 & 0.003 & 0.003 & 0.000 & 0.000 & 0.007 & 0.005 & 0.000 \\
\hline$(0.058)$ & $(0.058)$ & $(0.052)$ & 0.000 & 0.000 & $(0.081)$ & $(0.067)$ & 0.000 \\
\hline 0.503 & 0.514 & 0.355 & 0.451 & 0.385 & 0.307 & 0.310 & 0.288 \\
\hline$(0.500)$ & $(0.500)$ & $(0.479)$ & $(0.499)$ & $(0.487)$ & $(0.463)$ & $(0.463)$ & $(0.454)$ \\
\hline 0.433 & 0.427 & 0.522 & 0.463 & 0.496 & 0.556 & 0.554 & 0.576 \\
\hline$(0.496)$ & $(0.495)$ & $(0.500)$ & $(0.500)$ & $(0.501)$ & $(0.499)$ & $(0.498)$ & $(0.496)$ \\
\hline 0.064 & 0.059 & 0.123 & 0.086 & 0.120 & 0.137 & 0.137 & 0.136 \\
\hline$(0.245)$ & $(0.236)$ & $(0.329)$ & $(0.281)$ & $(0.325)$ & $(0.345)$ & $(0.344)$ & $(0.344)$ \\
\hline 0.211 & 0.215 & 0.160 & 0.157 & 0.237 & 0.159 & 0.102 & 0.117 \\
\hline$(0.408)$ & $(0.411)$ & $(0.367)$ & $(0.365)$ & $(0.426)$ & $(0.367)$ & $(0.303)$ & $(0.322)$ \\
\hline
\end{tabular}


Wave 1 Picture Vocabulary Test Score

Missing Data: Wave 1 Picture Vocabulary Test Score

Parental Income Wave 1

Missing Data: Parental Income Wave 1

Parent is Never Married in Wave 1

Parent is Married in Wave 1

Parent is Divorced, Separated or Widowed in Wave 1

Missing Data: Parents' Marital Status

Biological Mother's Education: Less than High School

Biological Mother's Education: High School Degree

Biological Mother's Education: Some College

Biological Mother's Education: College Degree or More

Biological Mother's Education: Not Known

\begin{tabular}{cccccccc}
0.009 & 0.008 & 0.014 & 0.017 & 0.015 & 0.013 & 0.014 & 0.016 \\
$(0.093)$ & $(0.091)$ & $(0.119)$ & $(0.130)$ & $(0.120)$ & $(0.114)$ & $(0.116)$ & $(0.125)$ \\
100.589 & 100.352 & 103.733 & 105.562 & 103.606 & 103.177 & 103.272 & 103.326 \\
$(14.542)$ & $(14.646)$ & $(12.679)$ & $(11.415)$ & $(12.607)$ & $(12.163)$ & $(13.381)$ & $(14.744)$ \\
0.048 & 0.047 & 0.057 & 0.034 & 0.047 & 0.039 & 0.080 & 0.052 \\
$(0.214)$ & $(0.212)$ & $(0.232)$ & $(0.183)$ & $(0.211)$ & $(0.195)$ & $(0.271)$ & $(0.223)$ \\
46.391 & 46.606 & 43.640 & 41.279 & 45.014 & 38.691 & 45.200 & 44.531 \\
$(50.474)$ & $(50.859)$ & $(45.190)$ & $(33.533)$ & $(61.055)$ & $(22.936)$ & $(38.965)$ & $(29.135)$ \\
0.241 & 0.242 & 0.223 & 0.160 & 0.184 & 0.281 & 0.260 & 0.241 \\
$(0.428)$ & $(0.429)$ & $(0.417)$ & $(0.368)$ & $(0.388)$ & $(0.451)$ & $(0.439)$ & $(0.429)$ \\
0.056 & 0.057 & 0.050 & 0.064 & 0.048 & 0.039 & 0.050 & 0.054 \\
$(0.230)$ & $(0.231)$ & $(0.219)$ & $(0.245)$ & $(0.215)$ & $(0.193)$ & $(0.219)$ & $(0.227)$ \\
0.711 & 0.711 & 0.703 & 0.688 & 0.694 & 0.723 & 0.709 & 0.699 \\
$(0.454)$ & $(0.453)$ & $(0.457)$ & $(0.465)$ & $(0.462)$ & $(0.449)$ & $(0.455)$ & $(0.460)$ \\
0.233 & 0.232 & 0.247 & 0.248 & 0.258 & 0.239 & 0.241 & 0.247 \\
$(0.423)$ & $(0.422)$ & $(0.432)$ & $(0.434)$ & $(0.438)$ & $(0.428)$ & $(0.428)$ & $(0.433)$ \\
0.136 & 0.137 & 0.122 & 0.103 & 0.096 & 0.150 & 0.139 & 0.131 \\
$(0.343)$ & $(0.344)$ & $(0.327)$ & $(0.305)$ & $(0.295)$ & $(0.359)$ & $(0.346)$ & $(0.338)$ \\
0.167 & 0.169 & 0.138 & 0.128 & 0.153 & 0.151 & 0.125 & 0.126 \\
$(0.373)$ & $(0.375)$ & $(0.345)$ & $(0.335)$ & $(0.361)$ & $(0.360)$ & $(0.331)$ & $(0.333)$ \\
0.337 & 0.337 & 0.341 & 0.343 & 0.332 & 0.355 & 0.342 & 0.305 \\
$(0.473)$ & $(0.473)$ & $(0.474)$ & $(0.476)$ & $(0.472)$ & $(0.480)$ & $(0.475)$ & $(0.462)$ \\
0.194 & 0.192 & 0.224 & 0.256 & 0.197 & 0.230 & 0.231 & 0.247 \\
$(0.396)$ & $(0.394)$ & $(0.417)$ & $(0.438)$ & $(0.398)$ & $(0.422)$ & $(0.422)$ & $(0.433)$ \\
0.259 & 0.259 & 0.259 & 0.244 & 0.259 & 0.257 & 0.266 & 0.300 \\
$(0.438)$ & $(0.438)$ & $(0.438)$ & $(0.431)$ & $(0.439)$ & $(0.438)$ & $(0.442)$ & $(0.460)$ \\
0.043 & 0.043 & 0.038 & 0.029 & 0.059 & 0.007 & 0.037 & 0.021 \\
$(0.202)$ & $(0.202)$ & $(0.192)$ & $(0.169)$ & $(0.236)$ & $(0.081)$ & $(0.189)$ & $(0.144)$ \\
& & & & & 153 & 439 & 191 \\
\hline 15699 & 14589 & 1110 & 175 & 343 & & &
\end{tabular}

Observations

14589

343

Unweighted means are obtained from Waves I and IV of the National Longitudinal Study of Adolescent Health. Standard deviations are in parentheses. 


\begin{tabular}{|c|c|c|c|c|c|}
\hline & (1) & (2) & & (1) & (2) \\
\hline & Combat & Firefight & & Combat & Firefight \\
\hline Some College or Training & $\begin{array}{l}-0.021 \\
(0.062)\end{array}$ & $\begin{array}{l}-0.134 \\
(0.089)\end{array}$ & Excellent Health & $\begin{array}{l}-0.076 \\
(0.059)\end{array}$ & $\begin{array}{l}-0.020 \\
(0.090)\end{array}$ \\
\hline College Degree & $\begin{array}{c}0.040 \\
(0.094)\end{array}$ & $\begin{array}{l}-0.195 \\
(0.139)\end{array}$ & Fair or Poor Health & $\begin{array}{c}0.049 \\
(0.079)\end{array}$ & $\begin{array}{l}-0.121 \\
(0.186)\end{array}$ \\
\hline Graduate/Professional Degree & $\begin{array}{c}-0.321 \\
(0.213)\end{array}$ & $\begin{array}{l}-0.015 \\
(0.257)\end{array}$ & Height in Inches & $\begin{array}{c}0.005 \\
(0.009)\end{array}$ & $\begin{array}{c}0.000 \\
(0.018)\end{array}$ \\
\hline Pre-Deployment Depression & $\begin{array}{c}0.076 \\
(0.098)\end{array}$ & $\begin{array}{c}-0.052 \\
(0.111)\end{array}$ & Weight in Pounds & $\begin{array}{c}-0.001 \\
(0.001)\end{array}$ & $\begin{array}{c}0.000 \\
(0.002)\end{array}$ \\
\hline Pre-Deployment Suicide & $\begin{array}{l}-0.069 \\
(0.083)\end{array}$ & $\begin{array}{c}0.025 \\
(0.179)\end{array}$ & Protestant & $\begin{array}{c}0.091 \\
(0.084)\end{array}$ & $\begin{array}{c}0.100 \\
(0.119)\end{array}$ \\
\hline Pre-Deployment Counseling & $\begin{array}{c}0.026 \\
(0.083)\end{array}$ & $\begin{array}{c}0.147 \\
(0.148)\end{array}$ & Catholic & $\begin{array}{c}0.059 \\
(0.104)\end{array}$ & $\begin{array}{c}0.003 \\
(0.134)\end{array}$ \\
\hline No Health Insurance & $\begin{array}{l}-0.003 \\
(0.080)\end{array}$ & $\begin{array}{c}0.113 \\
(0.109)\end{array}$ & Other Christian & $\begin{array}{c}0.052 \\
(0.076)\end{array}$ & $\begin{array}{l}-0.041 \\
(0.128)\end{array}$ \\
\hline Picture Vocabulary Test Score & $\begin{array}{c}0.001 \\
(0.002)\end{array}$ & $\begin{array}{l}-0.003 \\
(0.003)\end{array}$ & Other Religion & $\begin{array}{l}-0.123 \\
(0.118)\end{array}$ & $\begin{array}{l}-0.097 \\
(0.183)\end{array}$ \\
\hline Log of Parental Income & $\begin{array}{c}0.045 \\
(0.055)\end{array}$ & $\begin{array}{c}0.031 \\
(0.088)\end{array}$ & Male & $\begin{array}{c}0.126 \\
(0.077)\end{array}$ & $\begin{array}{l}0.284^{*} \\
(0.159)\end{array}$ \\
\hline Parent Married & $\begin{array}{l}-0.089 \\
(0.144)\end{array}$ & $\begin{array}{l}-0.067 \\
(0.215)\end{array}$ & Currently Married & $\begin{array}{c}0.003 \\
(0.082)\end{array}$ & $\begin{array}{c}0.032 \\
(0.083)\end{array}$ \\
\hline Parent Divorced/Separated/Widowed & $\begin{array}{c}-0.044 \\
(0.140)\end{array}$ & $\begin{array}{l}-0.022 \\
(0.207)\end{array}$ & Divorced & $\begin{array}{l}-0.026 \\
(0.068)\end{array}$ & $\begin{array}{l}-0.015 \\
(0.125)\end{array}$ \\
\hline Bio Mother has Some College & $\begin{array}{l}-0.003 \\
(0.055)\end{array}$ & $\begin{array}{c}-0.077 \\
(0.093)\end{array}$ & Age & $\begin{array}{l}-0.170 \\
(0.458)\end{array}$ & $\begin{array}{l}-0.826 \\
(0.896)\end{array}$ \\
\hline Bio Mother $\geq$ College Degree & $\begin{array}{l}-0.081 \\
(0.065)\end{array}$ & $\begin{array}{c}0.071 \\
(0.110)\end{array}$ & Age Squared & $\begin{array}{c}0.002 \\
(0.008)\end{array}$ & $\begin{array}{c}0.015 \\
(0.016)\end{array}$ \\
\hline Black & $\begin{array}{l}-0.025 \\
(0.080)\end{array}$ & $\begin{array}{l}-0.120 \\
(0.129)\end{array}$ & F-stat for family & & \\
\hline Other Race & $\begin{array}{c}0.235 * * * \\
(0.082)\end{array}$ & $\begin{array}{l}-0.160 \\
(0.142)\end{array}$ & $\begin{array}{l}\text { characteristics } \\
\text { F-stat for individual }\end{array}$ & 0.52 & 0.32 \\
\hline Hispanic & $\begin{array}{l}-0.035 \\
(0.079)\end{array}$ & $\begin{array}{l}-0.096 \\
(0.147)\end{array}$ & characteristics & 2.62 & 3.53 \\
\hline Log of Earnings & $\begin{array}{c}0.017 \\
(0.011)\end{array}$ & $\begin{array}{c}0.012 \\
(0.024)\end{array}$ & Observations & 573 & 411 \\
\hline
\end{tabular}

Robust standard errors corrected for clustering on the school are in parentheses. ${ }^{*},{ }^{* *}$, and $* * *$ indicate statistical significance at the $10 \%, 5 \%$, and $1 \%$ levels, respectively. All models use school fixed. Firefight specification controls for military variables which are rank, branch of service, timing of service, and occupation dummies. 


\section{Appendix Table 3. Stability of Estimates of the Mental Health Effects of Deployment Assignment to Added Controls, Military Population}

\begin{tabular}{lccccc}
\hline & $(1)$ & $(2)$ & $(3)$ & $(4)$ & $(5)$ \\
\hline & Individual & $(1)+$ & $(2)+$ & $(3)+$ & $(4)+$ Wave I \\
& Controls & Family & Health & Military & Mental \\
& & Controls & Controls & Controls & Health \\
\hline Panel A: Suicide & & & & &
\end{tabular}

Active Duty Military Service in Combat Zone

$\begin{array}{ccccc}0.028 & 0.031 & 0.036 & 0.051 & 0.048 \\ (0.031) & (0.031) & (0.030) & (0.034) & (0.033) \\ 0.015 & 0.019 & 0.022 & 0.028 & 0.027 \\ (0.038) & (0.037) & (0.037) & (0.040) & (0.039) \\ 0.021 & 0.023 & 0.026 & 0.044 & 0.041 \\ (0.033) & (0.033) & (0.033) & (0.037) & (0.037)\end{array}$

Active Duty Outside US in Non-Combat Zone

$1,063 \quad 1,063 \quad 1,063$

$1,063 \quad 1,063$

\section{Panel B: Depression}

Active Duty Military Service in Combat Zone

$\begin{array}{ccccc}0.039 & 0.044 & 0.047 & 0.053 & 0.049 \\ (0.044) & (0.044) & (0.044) & (0.047) & (0.045) \\ -0.011 & -0.008 & -0.007 & -0.010 & -0.004 \\ (0.054) & (0.055) & (0.055) & (0.058) & (0.056) \\ 0.016 & 0.023 & 0.025 & 0.034 & 0.036 \\ (0.039) & (0.039) & (0.039) & (0.042) & (0.042)\end{array}$

Active Duty Outside US in Non-Combat Zone

1,071

1,071

1,071

1,071

1,071

\section{Panel C: Counseling}

Active Duty Military Service in Combat Zone

$\begin{array}{ccccc}0.055^{*} & 0.063 * & 0.054 & 0.079 * * & 0.079 * * \\ (0.033) & (0.034) & (0.034) & (0.037) & (0.037) \\ -0.029 & -0.022 & -0.028 & 0.006 & 0.006 \\ (0.039) & (0.040) & (0.040) & (0.042) & (0.042) \\ -0.030 & -0.028 & -0.032 & -0.001 & -0.001 \\ (0.031) & (0.032) & (0.032) & (0.034) & (0.034)\end{array}$

Active Duty Outside US in Non-Combat Zone

1,072

1,072

1,072

1,072

1,072

\section{Panel D: PTSD}

Active Duty Military Service in Combat Zone

$\begin{array}{ccccc}0.118^{* * *} & 0.121 * * * & 0.113 * * * & 0.139 * * * & 0.139 * * * \\ (0.029) & (0.030) & (0.030) & (0.033) & (0.033) \\ -0.021 & -0.017 & -0.023 & 0.010 & 0.010 \\ (0.029) & (0.030) & (0.030) & (0.030) & (0.030) \\ -0.014 & -0.014 & -0.017 & 0.028 & 0.030 \\ (0.026) & (0.027) & (0.027) & (0.025) & (0.025)\end{array}$

Observations

$1,072 \quad 1,072$

1,072

1,072

1,072

Robust standard errors corrected for clustering on the school are in parentheses. ${ }^{*}, *$, and $* * *$ indicate statistical significance at the $10 \%, 5 \%$, and $1 \%$ levels, respectively. All models include school fixed effects. Individual controls are health, age, height, weight, religion, gender, race-ethnicity, income and PPVT score. Family controls are parental income, parental marital status and parental education during high school. Health controls are check-up in the past year and an indicator for health insurance status. Military controls are rank, branch of service, timing of service, and occupation dummies. 